\title{
A comparison of historical and paleoseismicity in a newly formed fault zone and a mature fault zone, North Canterbury, New Zealand
}

\author{
Hugh Cowan ${ }^{1}$ and Andrew Nicol ${ }^{2}$ \\ Department of Geology, University of Canterbury, Christchurch, New Zealand \\ Phillip Tonkin \\ Department of Soil Science, Lincoln University, Lincoln, New Zealand
}

Abstract. The timing of large Holocene prehistoric earthquakes is determined by dated surface ruptures and landslides at the edge of the Australia-Pacific plate boundary zone in North Canterbury, New Zealand. Collectively, these data indicate two large $(M>7)$ earthquakes during the last circa 2500 years, within a newly formed zone of hybrid strikeslip and thrust faulting herein described as the Porter's Pass-to-Amberley Fault Zone (PPAFZ). Two earlier events during the Holocene are also recognized, but the data prior to 2500 years are presumed to be incomplete. A return period of 1300-2000 years between large earthquakes in the PPAFZ is consistent with a late Holocene slip rate of 3-4 mm/yr if each displacement is in the range 4-8 m. Historical seismicity in the PPAFZ is characterized by frequent small and moderate magnitude earthquakes and a seismicity rate that is identical to a region surrounding the structurally mature Hope fault of the Marlborough Fault System farther north. This is despite an order-of-magnitude difference in slip rate between the respective fault zones and considerable differences in the recurrence rate of large earthquakes. The magnitude-frequency distribution in the Hope fault region is in accord with the characteristic earthquake model, whereas the rate of large earthquakes in the PPAFZ is approximated (but over predicted) by the Gutenberg-Richter model. The comparison of these two fault zones demonstrates the importance of the structural maturity of the fault zone in relation to seismicity rates inferred from recent, historical, and paleoseismic data.

\section{Introduction}

Earthquake hazard assessment traditionally incorporates the analysis of historic and contemporary seismicity, supplemented where possible by geological information about average slip rates, rupture lengths and slip per event. The timing and magnitude of prehistoric earthquakes resulting in surface rupture are determined by dating features offset by the fault and by examining the geometry of the fault trace. However, these data alone often do not provide sufficient information to characterize large paleoseismic events [e.g. Ward, 1994].

In North Canterbury, New Zealand, we have supplemented data from fault traces with data from landslides distributed throughout the eastern foothills of the Southern Alps. These data are used collectively to assess the late Holocene chronology of large

\footnotetext{
${ }^{1}$ Now at Norwegian Seismic Array, Kjeller, Norway.

${ }^{2}$ Now at Fault Analysis Group, Department of Earth Sciences, University of Liverpool, Liverpool, England.

Copyright 1996 by the American Geophysical Union.

Puper Number 95JB01588.

0148-0227/96/95JB-01588\$05.00
}

earthquakes in the Porter's Pass-to-Amberley Fault Zone (PPAFZ), a region of newly formed strike-slip faulting that defines the deformation front at the edge of the Australia-Pacific plate boundary zone in northeastern South Island.

North Canterbury straddles the edge of the Australia-Pacific plate boundary zone between the Hikurangi Trough and the Southern Alps (inset. Figure 1a). Dextral strike-slip faults of the Marlborough Fault System (MFS), farther north, transfer oblique plate motion between the Alpine fault and the Hikurangi subduction zone. These faults have smaller cumulative offsets toward the southeast but higher slip rates that reflect a southward relative migration of the locus of deformation across the region during the late Quaternary [e.g., Yeats and Berryman, 1987; H. Anderson et al., 1993]. The most southerly element of the MFS is the Hope fault (Figure 1a). Sixty kilometers south of the Hope fault, a zone of disseminated shear is evolving along a similar trend (Figure 1a) [Rynn and Scholz. 1978; Carter and Carter, 1982; Herzer and Bradshaw, 1985]. Elements of this zone comprise anastomosing strike-slip and thrust faults that extend east-northeast from the Southern Alps along the northern margin of the Canterbury Plains and pass into a fold and thrust belt near the town of Amberley (Figures la and 2). We use the name Porter's Pass-to-Amberley Fault Zone (PPAFZ) to describe the strike and approximate 


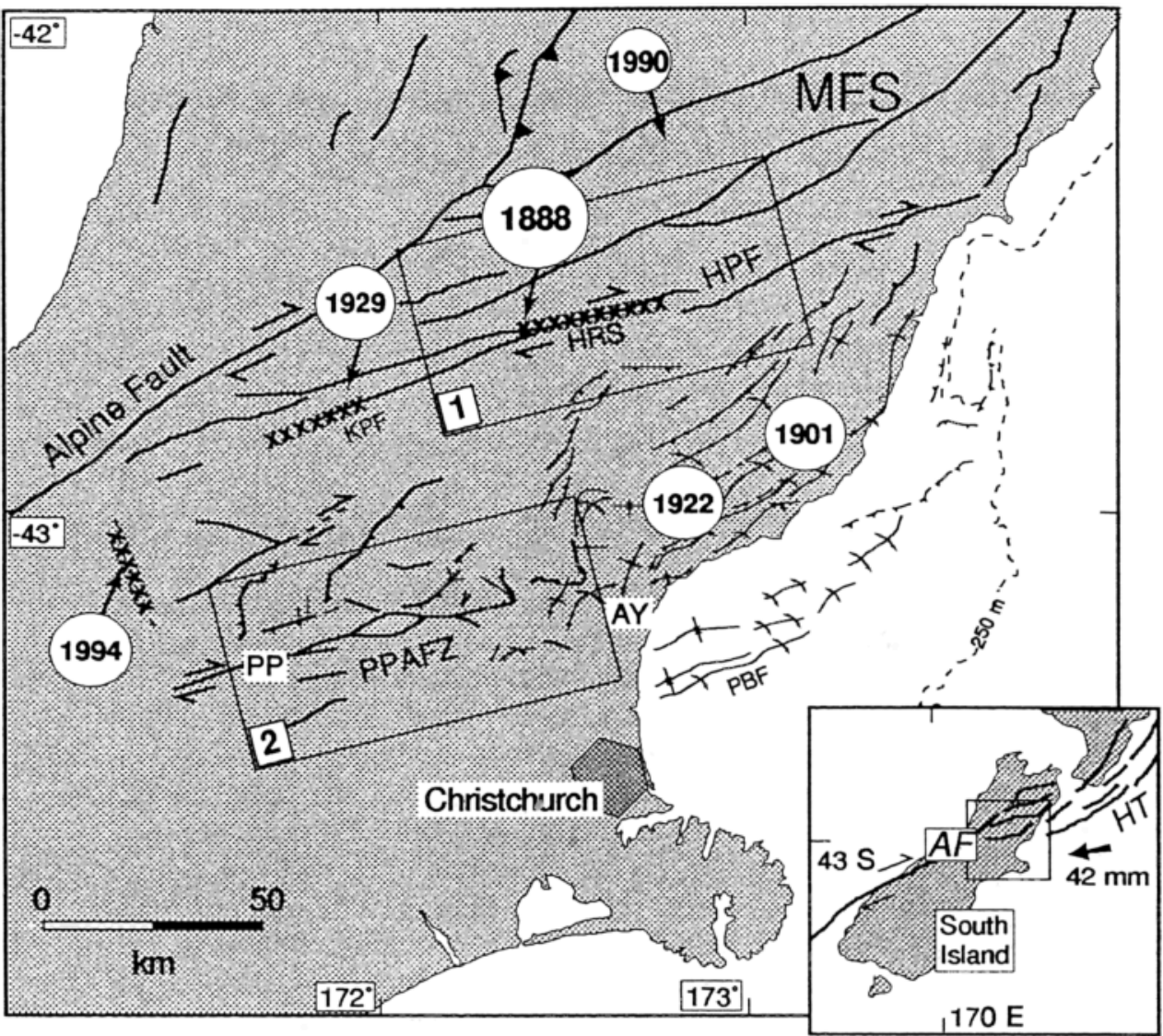

Figure 1a. Major structural elements of the northeastern South Island, and the locations and years of selected historical earthquakes. The onshore structure is modified from Gregg [1964], Cowan [1992] and unpublished data of the Active Tectonics Research Group, University of Canterbury. Offshore structure is simplified from Barnes [1994]. The numbered rectangles delineate two regions selected for analysis of historical seismicity. Abbreviations are MPS, Marlborough Fault System; HPF, Hope fault; HRS, Hope River segment; KPF, Kakapo fault; PPAFZ, Porter's Passto-Amberley Fault Zone; PBF, Pegasus Bay fault; PP, Porter's Pass; and AY, Amberley. Inset shows location of Figures $1 \mathrm{a}$ and $1 \mathrm{~b}$ in relation to the Alpine Fault (AF) and Hikurangi Trough (HT), the main elements of the New Zealand plate boundary. The arrow indicates the direction and magnitude ( $42 \mathrm{~mm} / \mathrm{yr}$ ) of the plate motion vector [DeMets et al., 1990].

geographic end-points of the zone, which has only recently been mapped comprehensively [Cowan, 1992].

The region between the Hope fault and PPAFZ is one of transition from subduction to collision [Reyners and Cowan, 1993]. where the geological structure of the upper crust is dominated by northeast striking reverse and thrust faults that dip southeast and are closely associated with growing folds [Yousif, 1987; Nicol et al., 1994]. This region has accommodated $\sim 12-15 \%$ northwestsoutheast shortening during the Pleistocene, and rates of shortening close to the Pacific coast are about 1\%/100 kyr [Nicol et al., 1994]. Detailed studies along the edge of the plate boundary zone in North Canterbury indicate that deformation probably commenced within the last $0.5-1 \mathrm{~m} . \mathrm{y}$., disrupting a volume of crust not significantly deformed since the Cretaceous [Cowan, 1992; Nicol et al., 1994].

The purpose of this paper is to evaluate the late Holocene record of large earthquakes in the PPAFZ, in order to understand the frequency-magnitude distribution of earthquakes in a newly formed fault zone. We compare historical and paleoseismic data from the PPAFZ with data from the adjacent structurally mature Hope fault zone, and use these data to evaluate differences in fault behavior between structurally mature and newly formed fault zones.

\section{Historic Seismicity of the North Canterbury Region}

Earthquakes within and adjoining the North Canterbury region during the period 1942-1994 are shown in Figure 1b, with those greater than magnitude 6.5 since 1888 indicated on Figure 1a. The focal depths for most events in the catalogue are uncertain due to the wide spacing of national network seismographs (typically $>50 \mathrm{~km}$ ), but local studies of microseismicity, recorded on portable, smallaperture seismograph arrays, have indicated that most earthquakes in this region are restricted to the upper $10-15 \mathrm{~km}$ of the crust [Rynn and Scholz. 1978; Cowan. 1992; Reyners and Cowan, 1993].

The Hope River segment of the Hope fault (Figure 1a) and an adjacent splay (Kakapo fault) have each ruptured during historic earthquakes of magnitude $M \sim 7.3$ and $M \sim 7.0$, respectively [Eiby, 1968; Cowan, 1991; Yang, 1991, 1992]. Two more events of magnitude 6.5-6.9 have occurred in the eastern part of North Canterbury, in 1901 and 1922, and another event of $M_{w} 6.7$ occurred in June 1994, to the west of the PPAFZ. The 1994 earthquate occurred in the upper crust, and the 1901 and 1922 events are presumed to have also been shallow, based on relatively limited falt areas [McKay, 1902; Skey, 1925]. Many more faults in North 


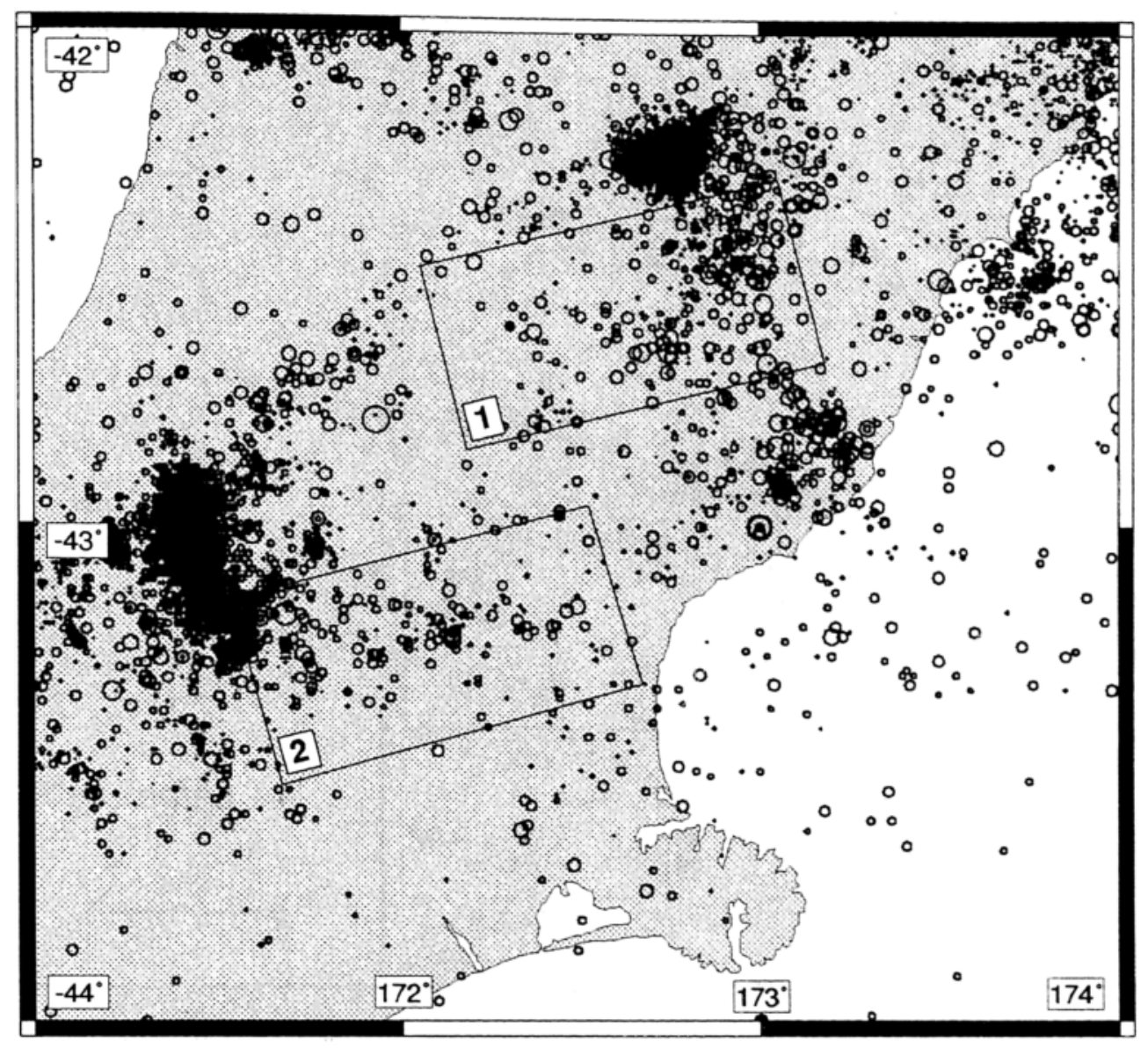

Figure 1b. Shallow seismicity $(<40 \mathrm{~km}$ ) for the region of Figure 1a during the period 1942-1994 (May 30) [New Zealand Seismological Observatory, 1994]. Symbols are scaled with magnitude, and the catalogue is complete above $M 3.0$ since 1988; $M 4.0$ since $1964 ; M 5.0$ since 1942. The dense clusters of seismicity, north of the Hope fault and west of the PPAFZ, are associated with earthquakes of $\mathrm{M}_{w} 5.9$ and $\mathrm{M}_{w} 6.7$, in 1990 and 1994, respectively [Anderson et al., 1993; Árnadóttir et al., in press].

Canterbury exhibit evidence of Holocene displacement [Gregg, 1964], and since 1964, the New Zealand national seismograph network has located frequent earthquakes of small to moderate magnitude $(M<5.4$ ) along the PPAFZ, making this one of the better defined surface fault zones in New Zealand [Reyners, 1989]. Data from the instrumental catalogue are utilized later in this paper for comparisons of recurrence parameters for large earthquakes within and between the Hope fault and PPAFZ regions.

\section{Porter's Pass-to-Amberley Fault Zone}

The PPAFZ extends east-northeast from the Southern Alps and passes into a fold and thrust belt near the town of Amberley and offshore (Figures 1a and 2) [Barnes, 1994; Nicol et al., 1994]. Principal elements of the PPAFZ bound the northern margin of the Canterbury Plains where the foothills of the Southern Alps rise to $2000 \mathrm{~m}$. The PPAFZ is defined by zones of crushed Torlesse greywacke that strike east and northeast, at a high angle to the regional NW-SE grain of Mesozoic deformation [Gregg, 1964]. and bocally cut through the late Cretaceous-Cenozoic cover sequence, disrupting late Pleistocene and Holocene landforms. A total offset of $<\mathrm{km}$ across the PPAFZ is inferred from the strike separation of
Oligocene and lower Miocene limestone beds across the Mount Grey block and vector analysis of slip across Mount Oxford (Figure 2) (H.A. Cowan et al., manuscript in preparation 1995).

The Porter's Pass fault forms the principal western element of the PPAFZ and is associated with Holocene offsets near Porter's -Pass [Speight, 1938: Wellman, 1953; Berryman, 1979; Coyle, 1988; Knuepfer, 1992]. New data on late Holocene faulting from this area are presented here. Farther east, the Porter's Pass fault bifurcates around Mount Oxford, and splays extend northeast and east to Lees Valley and the northern Canterbury Plains, respectively (Figure 2). A surface trace in Lees Valley is associated with scarps up to $6 \mathrm{~m}$ high on Holocene alluvial fans [Gregg, 1964; Garlick, 1992], and along the southern flank of the Ashley Range, major zones of crushed rock diverge to the east and southeast (Figure 2). The east striking zone extends into a region dominated by thrust faulting and folding centred on Mount Grey, whereas the southeast striking zone passes beneath the Canterbury Plains to the Cust anticline and Ashley fault and may extend offshore to the Pegasus Bay fault zone farther east [Kirkaldy and Thomas, 1963; Herzer and Bradshaw. 1985; Barnes, 1994] (Figure 1a). Data on late Holocene faulting and landslides in the eastern part of the PPAFZ have been collected from Cust anticline, Ashley fault, and Mount Grey. 


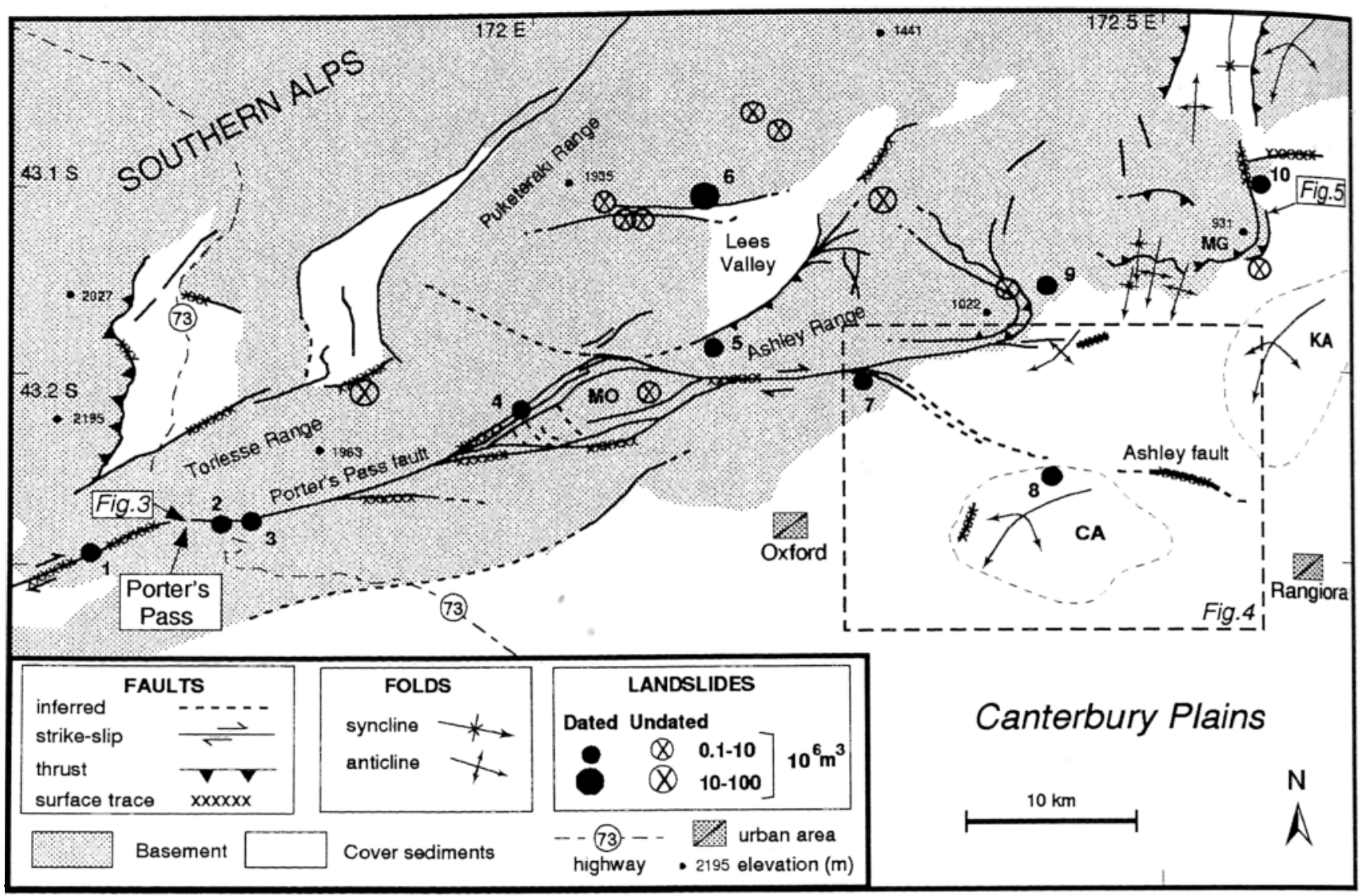

Figure 2. Structural elements of the Porter's Pass-to-Amberley Fault Zone (PPAFZ) in North Canterbury, New Zealand, showing the locations of main faults, folds, and prehistoric landslides. Faults that are depicted without sense-of-movement indicators represent mapped zones of crushed rock. Numbered landslides correspond to data in Table 2 and Figure 6 . Thin dashed lines denote the margins of active folds on the Canterbury Plains. Abbreviations are KA, Kowai anticline; CA. Cust anticline; MO, Mount Oxford, and MG, Mount Grey. The locations of Figures 3 , 4 , and 5 are indicated.

\section{Holocene Faulting in the PPAFZ}

\section{Porter's Pass Fault}

Studies near Porter's Pass, where the PPAFZ is relatively narrow, indicate a Holocene slip rate of $\sim 4 \mathrm{~mm} / \mathrm{yr}$ [Berryman, 1979] and 2.7-3.8 mm/yr [Knuepfer, 1992]. A few hundred meters north of Highway 73 at Porter's Pass (Figure 2), a radiocarbon date from the lower part of a peat column accumulated behind the surface trace indicates that the surface trace probably formed $2000-2500$ years B.P. (Table 1).

In a highway embankment on the south side of the pass, two buried soils, each containing charcoal, are offset across the fault (Figure 3 ). The crosscutting relationships together with the stratigraphy indicate possibly two ruptures during the Holocene (Table 1). The older of the two soils, offset across fault 1, may reflect a rupture between 7000 and 9000 years ago. Faults 2 and 3 have displaced both soils at least once since 7000 years ago.

\section{Cust Anticline}

The Cust anticline and Ashley fault, located on a major southeast splay of the PPAFZ, are important sites for paleoseismic investigation (Figures 2,4). The recent nature of the deformation in this region is indicated by the presence of consolidated Plioceneearly Quaternary siltstone and conglomerate which crops out to a height of $150 \mathrm{~m}$ on the northern flank of Cust anticline. A steep north-to-south gradient of Bouguer gravity anomalies across the anticline has been attributed to the presence of a fault with significant throw [Kirkaldy and Thomas, 1963]. We infer that this fault is connected to the southeast striking extension of the Porter's Pass fault at Glentui River, which appears to control the flow direction of the Ashley River in the area immediately to the northwest of Cust anticline (Figure 4).

Late Quaternary uplift of Cust anticline is evident from drainage features preserved across the crest of the fold, which is capped by two late Pleistocene loess sheets [Trangmar, 1987]. Ancestral channels of the Ashley River are incised into the loess sheets (Figure 4), so the diversion of Ashley River to its present course has presumably accompanied uplift at the western margin of the anticline, possibly during the early Holocene since the youngest ancestral channel has no loess cover. The uplift was probably caused by rupture on a fault that is associated with a $1.5-\mathrm{km}$ - long surface trace (Figure 4) and a large $(-500 \mathrm{~m})$ offset in basement [Kirkaldy and Thomas, 1963].

Probable late Holocene ruptures in this area are inferred from dated landslides and the timing of Ashley River downcutting along the northern flank of the anticline. Wood collected from the base of gravel deposits overlying the strath of a terrace $13 \pm 12 \mathrm{~m}$ above the Ashley River was dated at between 2100 and 2500 calibrated radiocarbon years old (Table 1 and Figure 4), implying an aver 


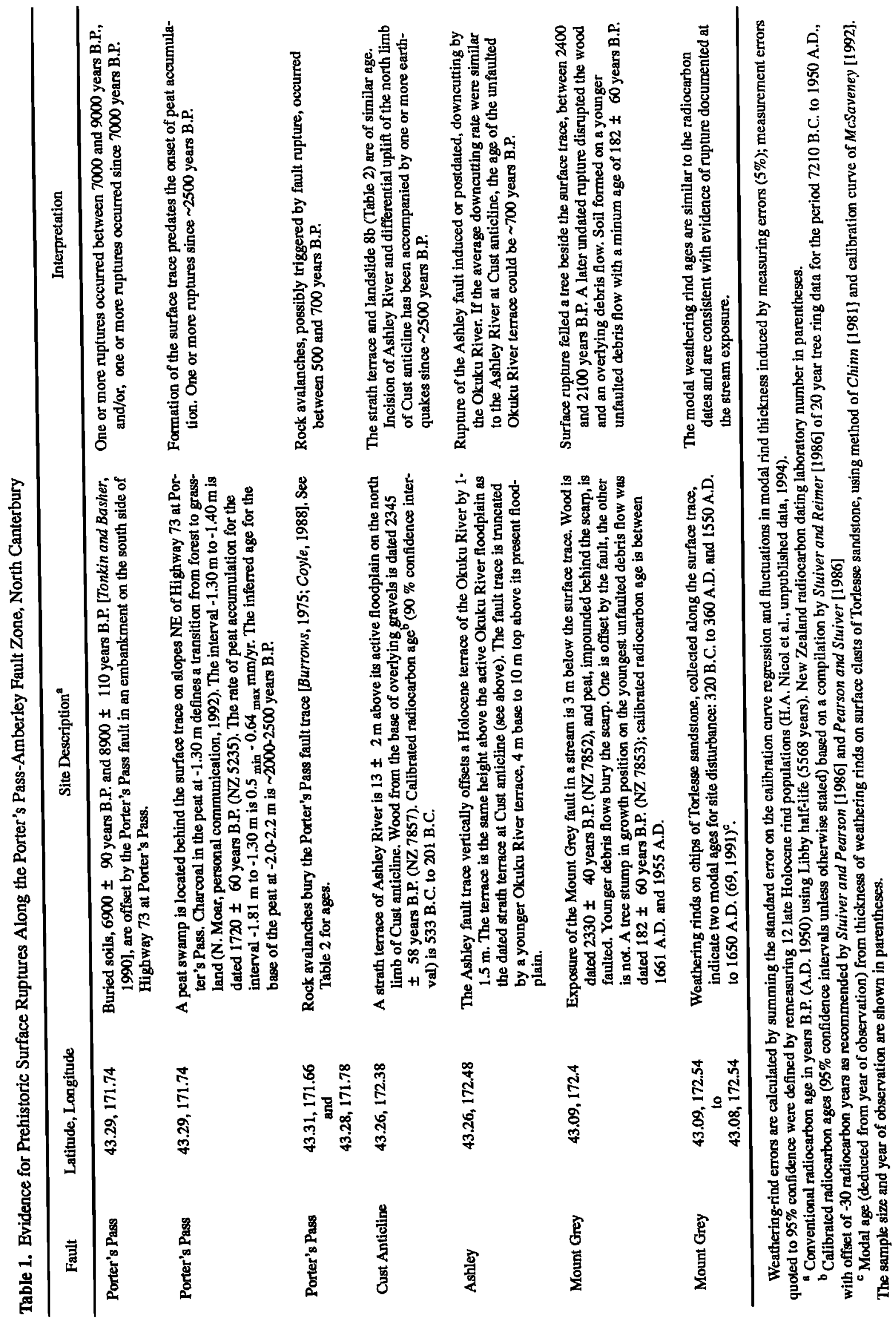




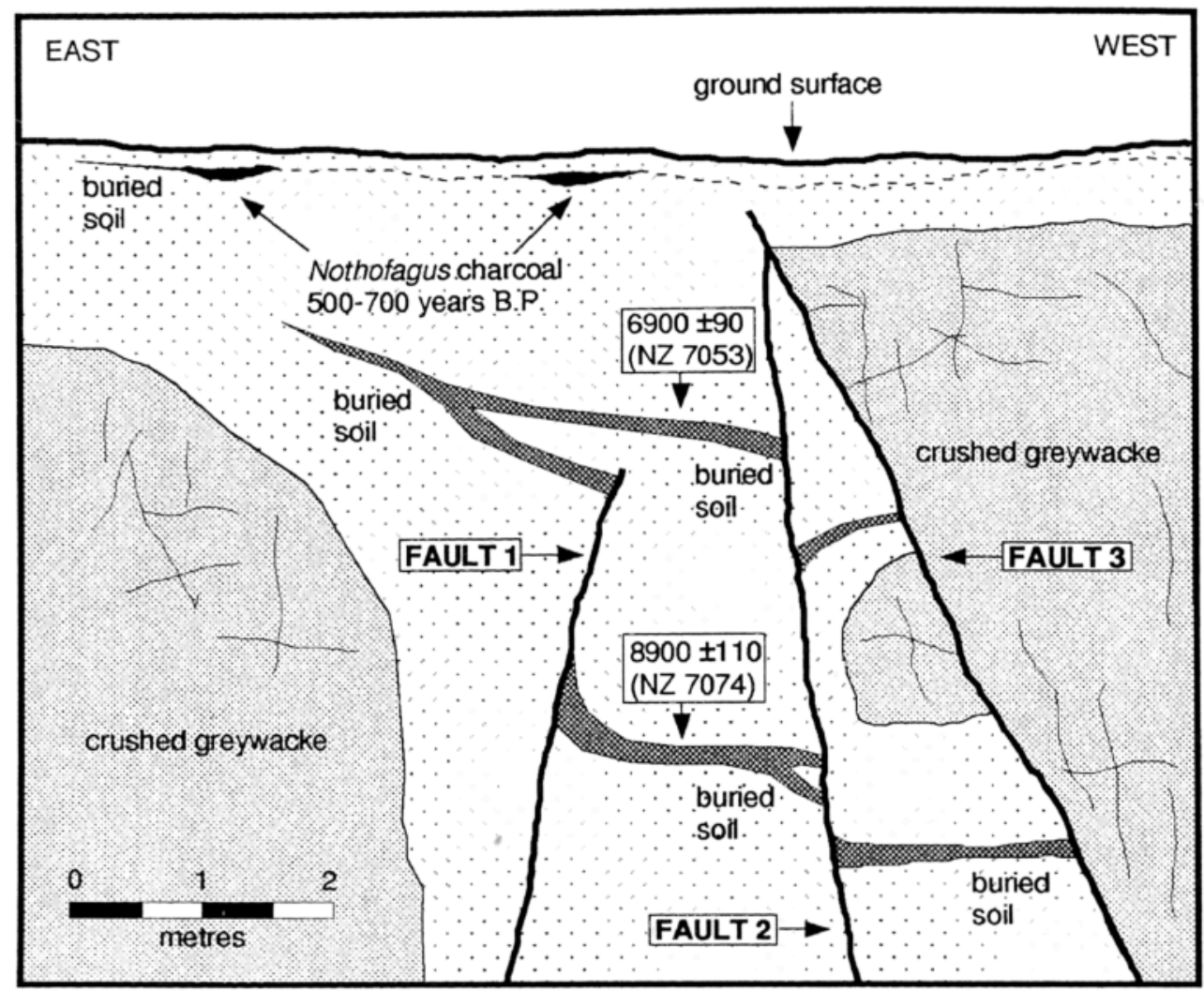

Figure 3. Age relations between faults and buried soils exposed in a road embankment within the Porter's Pass fault zone at Porter's Pass. See Figure 2 and Table 1 for site location and description, respectively.

downcutting rate of $5.7 \pm 1.4 \mathrm{~m} / \mathrm{kyr}$. The height of the terrace strath above the present floodplain presumably reflects an element of tectonic uplift and fold growth, because upstream the river is in equilibrium, whereas downstream it is aggrading [Cowan, 1992], Whether or not the downcutting by Ashley River reflects continuous or episodic uplift is unclear, but additional data from landslides at this locality (Figure 4) suggest that the first increment of uplift was induced by coseismic rupture in this sector of the PPAFZ.

\section{Ashley Fault}

The Ashley fault offsets Pleistocene and Holocene terraces of the Okuku River east of Cust anticline and has a surface trace length of $4.5 \mathrm{~km}$ [Brown, 1973; Berryman, 1979] (Figure 4). The fault is downthrown to the south, with throws of 1-4 m on a late Pleistocene aggradation surface and $0.5-1.5 \mathrm{~m}$ on a Holocene strath terrace [Cowan, 1992]. Differences in the throw of the fault on these two surfaces suggest at least two ruptures since the formation of the late Pleistocene aggradation surface. Variations in throw which accompany slight changes in the strike of the fault, are consistent with a minor right-lateral component of displacement, but no unequivocal offsets have been documented.

The height of the Holocene strath terrace offset by the Ashley fault is similar to the dated (i.e., $13 \mathrm{~m}$ ) strath above Ashley River, so the terraces may be of approximately equal age. The fault trace across the Okuku River strath is not significantly degraded, so the river presumably abandoned the surface prior to, or at the time of, faulting. The oldest Okuku River terrace not offset by the fault (its riser truncates the surface trace) is about $4 \mathrm{~m}$ above the active floodplain (Figure 4). If the average downcutting rate of the Okuku
River is similar to the Ashley River, then the unfaulted terrece formed $-600-900$ years ago. The available data thus imply that the last rupture of the Ashley fault postdated 2500 years B.P. and could have accompanied the growth of Cust anticline prior to $600-900$ years B.P.

\section{Mount Grey Fault}

The Mount Grey fault comprises a north dipping thrust along the south side of Mount Grey $(931 \mathrm{~m}$ ) in the eastern part of the PPAFZ (Figure 2). The fault loops around the eastern flank of Mount Gey and bifurcates, forming an oblique, left-lateral tear fault that strikes north and dips to the west, and against which the Tertiary cover sequence has been overturned [Wilson, 1963]. The fault is exposed in a number of streams and forms a prominent surface trace and hillside bench hollow, behind which scree and boulders heve accumulated.

Radiocarbon and weathering-rind dates delineate two surfece rupture events within the last 2500 years (Table 1). Evidence for the oldest recognized event was obtained from a stream bank exposure of the fault (Figure 2,5), where wood and peat were preserved on the surface of a debris flow, offset across a fault scarp that is now buried $3 \mathrm{~m}$ below the present ground surface. The wood was not in growth position and was buried beneath younger colluvium, which in turn was offset by the fault. A soil, developed on the debris fiow and containing a trace of charcoal of unknown age defined apparent vertical offset (downthrown to the west) across the faul We could not discern from the field relationships whether or not this buried soil was deformed or had merely developed on an expoed fault scarp at a later date. The soil was buried beneath another dobris flow, also capped by a younger soil profile containing a tree stuine 


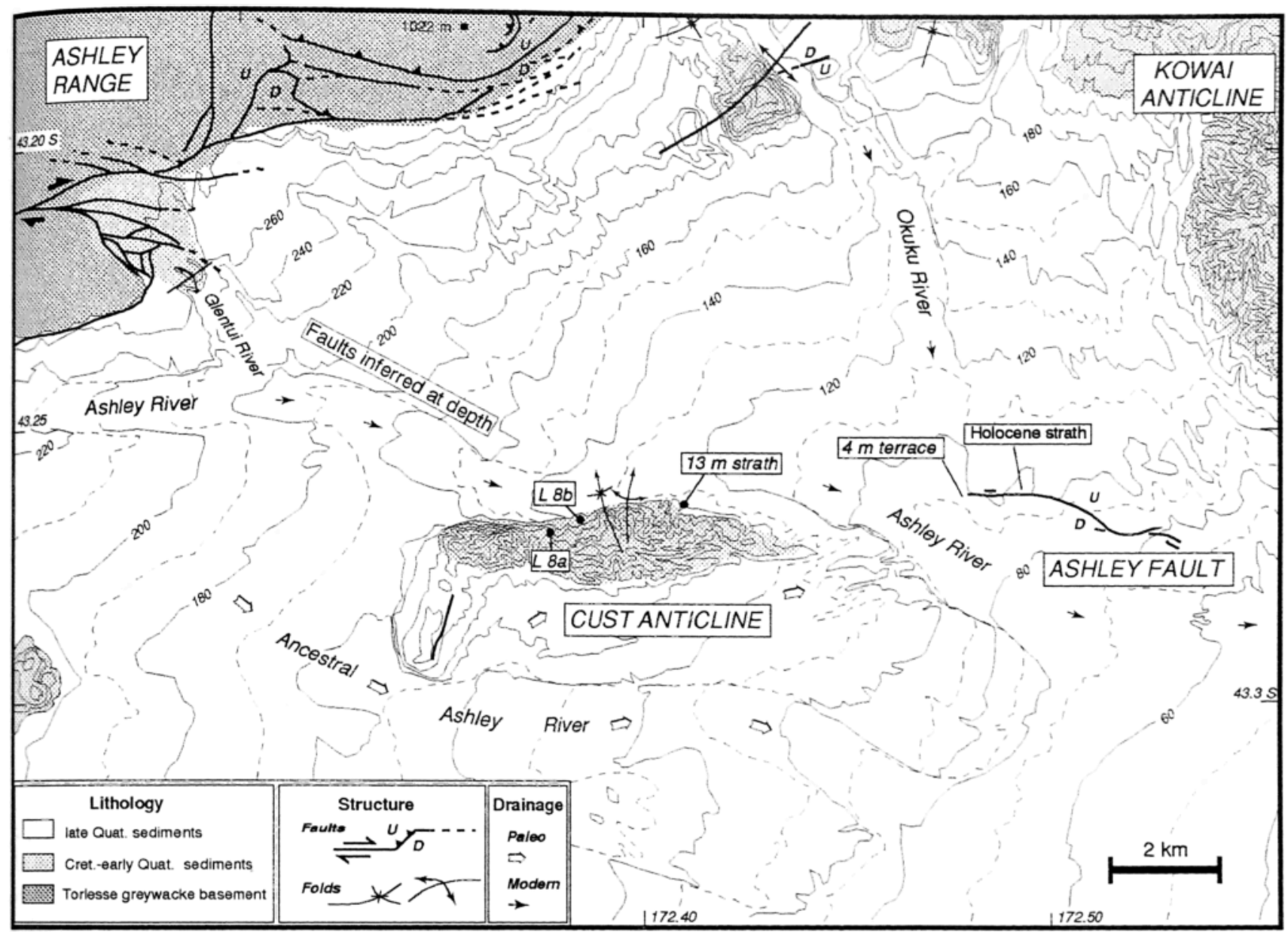

Figure 4. Map of the northern Canterbury Plains showing the relationships between the Cust anticline, Ashley fault, and range-bounding elements of the PPAFZ. L8a and L8b indicate locations of the radiocarbon dates from landslide 8 (Table 2 and Figure 6). Topographic contours are reproduced at $20-\mathrm{m}$ and $10-\mathrm{m}$ intervals (thin solid and thin dashed lines, respectively) from NZMS 270, sheets L35 and M35, by permission of the Department of Survey and Land Information, New Zealand.

in growth position. A radiocarbon date of $182 \pm 60$ years B.P. obtained from an outer portion of the tree stump (Table 1) indicated a minimum age for the buried soil and the last surface rupture recognized at this site.

Chips were collected from Torlesse sandstone boulders and cobbles exposed at the ground surface along the fault trace north of the stream bank locality, and weathering-rind ages for these were calculated using the method of Chinn [1981] and calibration curve of McSaveney [1992] to evaluate the timing of site disturbance. Two modal rind thicknesses were obtained and the ages (Table 1) are in good agreement with the time intervals for which surface rupture is inferred from the radiocarbon ages. The available data collectively imply surface rupture on the Mount Grey fault, between 2300-2400 years B.P. and $300-450$ years B.P.

\section{Prehistoric Landslides of the PPAFZ}

Landslides provide additional data with which to assess the reourrence interval of large prehistoric earthquakes in the PPAFZ. Twenty landslides have been identified within the PPAFZ, and the aes for 10 of these have been determined from radiocarbon and weathering-rind dating (Table 2). The landslides are mostly large $\left(0.2-10 \times 10^{6} \mathrm{~m}^{3}\right)$ rock avalanches, derived from outcrops of Torlesse basement (Figure 2). The data indicate a clustering of ages between about 500 and 700 years B.P., with others scattered back to more than 7000 years B.P. (Table 2 and Figure 6).

Landslides in the range 500-700 years B.P. are relatively uniformly distributed along the PPAFZ and are well preserved. However, there are insufficient data to confirm a similar spatial pattern of landslides at 2300 years or older, which presumably reflects the removal of landslide debris by erosion. A large landslide identified on the north limb of Cust anticline (Figure 4), which contained whole trees and an articulated skeleton of the largest species of extinct moa, Diornis giganteus [Cowan. 1992], was radiocarbon dated at circa 2300 years B.P. (Table 2). This age is the same as the nearby strath terrace of Ashley River (Figure 4), and we surmise that both the landslide and the onset of river downcutting accompanied coseismic uplift of Cust anticline.

To assess whether the effects of this event extended beyond the geographic limits of our study, the ages of rock avalanches from the central Southern Alps [Whitehouse and Griffiths, 1983] were recalculated using the weathering-rind calibration curve of McSaveney [1992]. Two modal ages were obtained for Southern Alps landslides (circa 1050-1400 years B.P. and circa 1700-2100 years B.P.), and these do not coincide with modal ages for landslides 


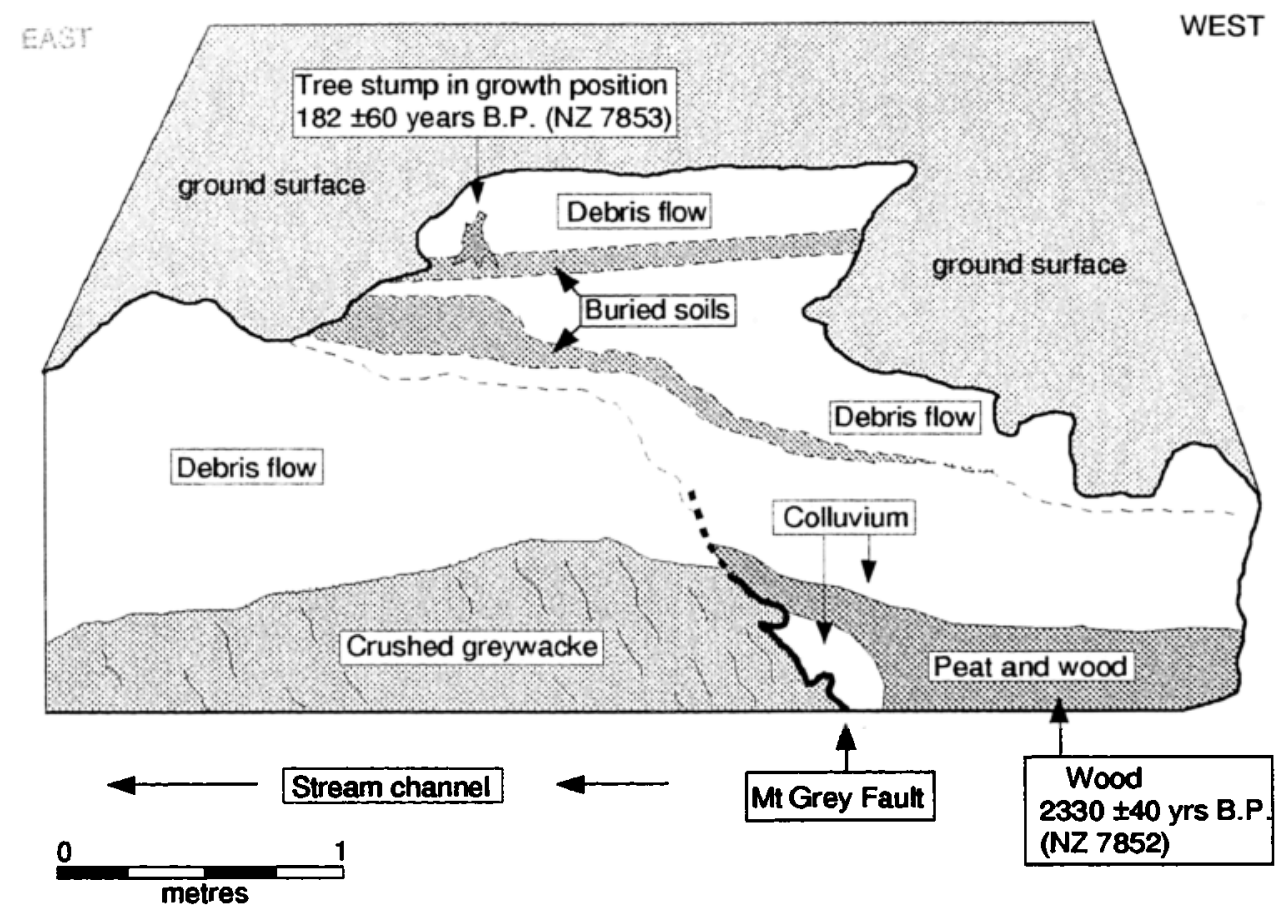

Figure 5. Stratigraphy and conventional radiocarbon ages associated with samples from an exposure of the Mount Grey fault in a stream bank on the eastern flank of Mount Grey. See Figure 2 and Table 1 for site location and description, respectively.

documented in the PPAFZ (Figure 6). The ages for three landslides from the central Southern Alps do overlap with those of the PPAFZ, in the range $\sim 2200-2450$ years B.P., but fault data indicate probable rupture of the PPAFZ during that period (Table 1).

Six landslides with ages between 500 and 700 years B.P. are located within $1 \mathrm{~km}$ of the major faults of the PPAFZ, and two of these bury the trace of the Porter's Pass fault near Porter's Pass (Figure 2, landslides 1 and 2 ). By contrast, only two landslides within this age range were dated by Whitehouse and Griffiths [1983] in the Southern Alps farther west. Collectively, the spatial distribution of these data suggests that if the landslides were seismically triggered, they are more likely related to local rupture of the PPAFZ rather than to a regional event on the Alpine Fault, an interpretation favored by W.B. Bull (personal communication. 1994) based on recent lichenometric dating of landslides in the Southern Alps.

The interpretation of landslide distributions in paleoseismology involves two assumptions: (1) that landslides were triggered coseismically; and (2) that all landslides of a similar age were coseismic with the same event. Landslides have been triggered by all large $(M>7)$ historic earthquakes in New Zealand, but many large landslides in seismically active regions, including the Southern Alps, have not been triggered by earthquakes [e.g., Plafker and Ericksen. 1978; McSaveney et al., 1992; McSaveney. 1978, 1993]. In the absence of independent evidence, the coseismic interpretation of prehistoric landslides must therefore be regarded as tentative [Whitehouse and Griffiths, 1983].

For both fault traces and landslides there are at least two reasons why evidence for large paleoearthquakes could be sparse. First, it must be remembered that few dating techniques can discriminate events separated by a few years or decades, a point exemplified by three historic earthquakes in northern South Island. Both the $M_{\mathrm{s}} 7.8$ Buller and $M_{s} 7.0$ Arthur's Pass earthquakes of 1929 [Henderson, 1937; Speight, 1933; Dowrick and Smith, 1990] occurred within a period of 3 months and were followed 39 years later by the $M_{3} 7.4$, $M_{w} 7.1$ Inangahua earthquake [Adams et al., 1968; Anderson et al., 1994]. It is doubtful whether each of these events could be differentiated from the geological record using radiocarbon deting had they occurred during prehistoric time, although dendrochronology and lichenometry could potentially discriminate the 1929 and 1968 events [e.g., Bull et al., 1994]. Second, as the elapsed time since the creation of a landform increases, so too does the likelihood that it will be destroyed, modified, or buried by subsequent processes. Furthermore, periods of non deposition may conceal the occurrence of rupture events at a given site, and assumptions of continuous sedimentation are difficult to test and are rarely proven [e.g. Doig, 1990; Cowan and McGlone, 1991]. Wh cannot rule out periods of non deposition at any of the sites described in this study, but the temporal clustering of landslides in the range 500-700 years B.P. and their close proximity to the PPAFZ suggest that the most recent rupture of this zone probably occurned during that period. The landslides attributed to earlier events (20002500 years B.P. and 7000-9000 years B.P.) are much less abundant, indicating that in New Zealand's mountainous terrain, landside data may only be useful for characterising paleoseismicity for up to 2000-3000 years B.P.

\section{Magnitude Estimates}

The dating of surface fault ruptures provides a check on the likelihood that a given group of landslides was triggered coseismically, but the estimation of magnitude is problematic in the absence of data that define the rupture dimensions, and these parameters are poorly constrained for the PPAFZ. Relationstips between landslide distributions and earthquake magnitudes hav been proposed based on global compilations of data from histocic events [Keefer, 1984], but these probably do not provide appropriate basis for estimating the magnitude of prehistorit 
Table 2. Description of Dated Landslides From the Porter's Pass-Amberley Fault Zone

\begin{tabular}{|c|c|c|c|c|c|}
\hline $\begin{array}{l}\text { Locality From } \\
\text { Figure } 2\end{array}$ & Latitude, Longitude & $\begin{array}{l}\text { Landslide Volume, } \\
\qquad 10^{6} \mathrm{~m}^{3}\end{array}$ & Age $^{\mathrm{a}}$ & Method $^{b}$ & Age Calendar Years ${ }^{\circ}$ \\
\hline 1, Acheron River & $43.31,171.66$ & $\begin{array}{l}6.0 \\
\text { two slidese }\end{array}$ & $500 \pm 69^{\circ}$ & $\begin{array}{c}{ }^{14} \mathrm{C} \\
\text { NZ } 547\end{array}$ & A.D. $1290-1515^{\mathrm{f}}$ \\
\hline 2, Kowai River & $43.28,171.78$ & 2.0 & $560 \pm 90$ & $\begin{array}{c}\text { WR } \\
60,1988\end{array}$ & A.D. $1340-1520$ \\
\hline 3, Kowai Riverg & $43.28,171.80$ & 0.2 & $590 \pm 100$ & $\begin{array}{c}\text { WR } \\
40,1988\end{array}$ & A.D. $1300-1500$ \\
\hline 4, Coal Creek & $43.40,172.00$ & 0.02 & $5600 \pm 62$ & $\begin{array}{c}{ }^{14} \mathrm{C} \\
\mathrm{NZ} 7918\end{array}$ & 4575-4335 B.C. ${ }^{f}$ \\
\hline 5, Ashley Gorge & $43.19,172.14$ & 0.3 & $490 \pm 70$ & $\begin{array}{c}\text { WR } \\
75,1991\end{array}$ & A.D. $1430-1570$ \\
\hline 6, Lees Valley & $43.11,172.12$ & 10.0 & $580 \pm 90$ & $\begin{array}{c}\text { WR } \\
62,1991\end{array}$ & A.D. $1320-1500$ \\
\hline 7. Glentui River & $43.21,172.26$ & $\begin{array}{c}4.0 \\
\text { two slides }\end{array}$ & $\begin{array}{c}600 \pm 100 \\
1210 \pm 190\end{array}$ & $\begin{array}{c}\text { WR } \\
70,1991 \\
\text { WR } \\
45,1991\end{array}$ & $\begin{array}{l}\text { A.D. } 1290-1490 \\
\text { A.D. } 590-970\end{array}$ \\
\hline 8a, Cust Anticline & $43.26,172.37$ & 0.1 & $7400 \pm 90$ & $\begin{array}{c}{ }^{14} \mathrm{C} \\
\mathrm{NZ} 7854\end{array}$ & $6425-6000$ B.C.f \\
\hline 8b, Cust Anticline & $43.26,172.37$ & 3.0 & $\begin{array}{l}2300 \pm 60 \\
2270 \pm 82\end{array}$ & $\begin{array}{c}{ }^{14} \mathrm{C} \\
\mathrm{NZ}^{7855} \\
{ }^{14} \mathrm{C} \\
\mathrm{NZ} 7856\end{array}$ & $\begin{array}{l}\text { mean of two dates } \\
200-400 \text { B.C. }\end{array}$ \\
\hline 9, Mount Thomas & $43.15,172.40$ & 4.0 & $2467 \pm 66$ & $\begin{array}{c}{ }^{14} \mathrm{C} \\
\mathrm{NZ} 7895\end{array}$ & $400-765$ B..$^{f f}$ \\
\hline 10, Mount Grey & $43.09,172.55$ & 0.2 & $\begin{array}{c}3430 \pm 470 \\
\text { bimodal } \\
4580 \pm 660\end{array}$ & $\begin{array}{c}\text { WR } \\
99,1991\end{array}$ & $\begin{array}{l}\text { 970-1400 B.C. } \\
\text { 1930-3250 B.C. }\end{array}$ \\
\hline
\end{tabular}

See Table 1 footnote for explanation of weathering-rind dating errors.

${ }^{2}$ Years before A.D. 1950, with modal weathering rind ages rounded to nearest 5 years.

${ }^{b}$ Symbol ${ }^{14} \mathrm{C}$ denotes conventional radiocarbon age and sample numbers; WR is weathering rinds, followed by number of rinds and year (A.D.) of measurement.

${ }^{\circ}$ Symbol ${ }^{14} \mathrm{C}$ ages (calendar years A.D./B.C.).

'Data from Burrow's [1975].

'Data from W.B. Bull (written communication, 1994).

${ }^{f}$ Calibrated radiocarbon ages (95\% confidence levels unless otherwise stated) based on compilation by Stuiver and Reimer [1986] of 20-year tree ring data for the period 7210 B.C. to A.D. 1950, with offset of -30 radiocarbon years as recommended by Stuiver and Pearson [1986] and Pearson and Stuiver [1986].

8 Data from Coyle [1988].

earthquakes. Only the largest prehistoric rock falls may be recognized, and variations in earthquake source mechanism and regional geology could strongly influence the distribution of landslides. For example, the 1929 and 1994 Arthur's Pass earthquakes each triggered rock falls over an area comparable to many global events of similar magnitude (M. McSaveney, personal communication, 1995), but the areas affected by large landslides of the 1929 Buller and 1968 Inangahua earthquakes [Adams, 1981] are smaller than might be expected from Keefer's global catalogue. The Buller and Inangahua earthquakes occurred in a region composed largely of crystalline Paleozoic rocks, in contrast to the weakly metamorphosed greywacke of the Southern Alps. These differences, together with variations in focal depth, rupture directivity, and topographic effects illustrate some of the uncertainties that would accompany the estimation of earthquake mognitudes from prehistoric landslide distributions. The uncertainties naturally would be compounded by incomplete sampling of the spatial distribution of prehistoric landslides.
The threshold magnitude for surface rupture and coseismic landsliding in the PPAFZ is unclear. However, since all historic earthquakes larger than magnitude $M \sim 7$ in northem South Island have been accompanied by landslides [McKay, 1902; Henderson, 1937; Speight, 1933; Adams et al., 1968] we infer that the late Holocene landslides in the PPAFZ were probably triggered by earthquakes of similar magnitude. More precise estimates of magnitude would depend critically on detailed knowledge of the sub-surface fault dimensions and segmentation [Wells and Coppersmith, 1994], parameters that are poorly defined in this bybrid strike-slip and thrust fault zone. Indeed, lateral variations in fault behavior are to be expected, and historic earthquakes elsewhere [e.g., Amaike, 1987; Stein and Yeats, 1989; Hull, 1990; Stein and Ekstrøm, 1992; Smalley et al., 1993; Anderson et al., 1994; Jibson et al., 1994] suggest that not all Holocene ruptures in the PPAFZ would necessarily produce surface fault offsets indicative of earthquake magnitude or amenable to paleoseismic investigation. This seems especially likely in the fold and thrust belt 


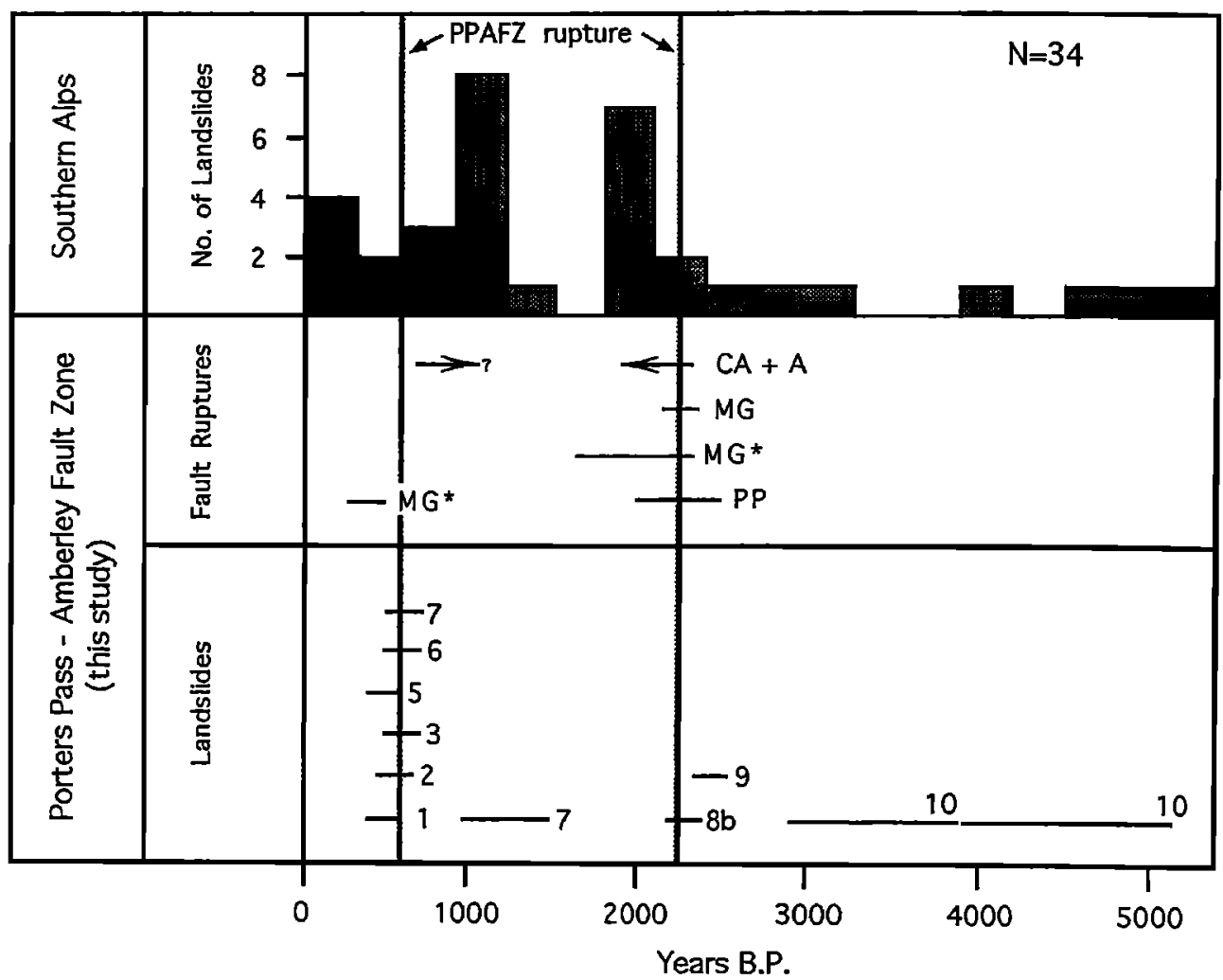

Figure 6. Temporal distribution of landslides and fault ruptures in the PPAFZ, and a comparison with dated landslides from the Southem Alps [Whitehouse and Griffiths, 1983]. Weathering-rind ages from the Southern Alps have been recalibrated using the calibration curve of McSaveney [1992]. Landslide numbers correspond to those in Table 2 and are located on Figure 2. Abbreviations are A, Ashley fault; CA, Cust anticline; MG. Mount Grey fault; PP, Porter's Pass fault. Asterisks denote fault ruptures dated by weathering rinds. Refer to Tables 1 and 2 for details of fault ruptures and landslides, respectively.

at the eastern end of the PPAFZ and farther north, where late Holocene surface traces are preserved, but locally display vertical offsets that are anomalously large with respect to fault length and for which no landslides have been correlated [Cowan, 1994; A. Nicol et al., unpublished data, 1991]. Uncertainties in the assessment of fault dimensions and the likelihood of hidden faults in this young fault zone also complicate the estimation of slip rate and potential slip per event. Local variations in fault kinematics are evident from the differential uplift at Cust anticline (this study) and in the fold and thrust belt farther east [Nicol et al., 1994]. Davis and Namson [1994] and Shaw and Suppe [1994] have shown that detailed structural analysis can reveal the presence of hidden faults, and similar work in progress in the PPAFZ (H.A. Cowan et al., manuscript in preparation, 1995) may provide further insight into the kinematics and subsurface structure of the zone, especially if combined with recent observations of geodetic strain (C.F. Pearson et al., Strain distribution across the Australian-Pacific plate boundary in the central South Island, New Zealand, from 1992 GPS and earlier terrestrial observations, submitted to Journal of Geophysical Research; hereinafter Pearson et al; submitted manuscript, 1995). Here, we restrict our discussion to the implications of available historical and paleoseismic data for analysis of seismicity rates and fault behavior.

\section{Seismicity Rate Analysis}

The traditional approach to seismicity rate analysis is to assume a uniform spatial distribution of earthquakes and an exponential distribution of magnitudes of the Gutenberg-Richter form:

$$
\log N(M)=a-b M
$$

where $N(M)$ is the cumulative number of earthquakes of magnitude equal to or greater than $(M)$; a defines the rate of occurrence, and $b$ is the exponential decay with increasing magnitude, implying self-similarity [e.g., King. 1983]. The parameters $a$ and $b$ are constants of the seismicity model and are computed from a catalogue of historical seismicity. Equation (1) may be integrated to obtain a cumulative exponential distribution, truncated at a maximum magnitude for a given set of faults or volume of crust, such that

$$
N=N_{\mathrm{o}}\left[10^{b(M 0-M)}-10^{b(M 0-M \max )}\right]
$$

$N_{0}$ is the number of earthquakes of magnitude $M_{0}$ or greater, where $M_{0}$ is an arbitrary threshold magnitude [e.g., Youngs and Coppersmith, 1985]. When combined with an appropriate attenuation expression, the seismicity model may be used to derive return periods or probabilities of exceedance for specified levels of ground motion. This classical hazard analysis, advanced by Coratl [1968], has been applied widely in seismic hazard assessment [set J.G. Anderson et al., 1993] and in New Zealand by, among others, Peek et al. [1980] and Smith and Berryman [1986].

Studies of individual faults have shown that the recurrence ras of large earthquakes $(M>7)$ may be under-predicted by the $b$ value model [e.g., Wesnousky et al., 1983; Schwartz and Coppersmith 1984; Davison and Scholz, 1985]. Rather, the frequency of large events appears to be governed by relations between fall geometry, segmentation, and cumulative geological offset, which influence the distribution of strength properties along fault zones 
[e.g., King and Nabelek, 1985; Sibson, 1989; Wesnousky, 1988, 1990]. The recognition of structural controls on the propagation, arrest, and subsequent slip distribution associated with some coseismic fault ruptures [e.g., Sibson, 1985, 1989] has drawn stention to the significance of fault segmentation as a possible indicator of the size of earthquakes associated with a given fault. This concept is implicit in the model of "characteristic" earthquake reaurrence in which most of the deformation associated with a given fault or segment is released coseismically by earthquakes that occur within a relatively narrow recurrence time and magnitude distribution [Working Group on California Earthquake Probabilities, 1990]. Other models advanced to explain geological evidence of time-variable and slip-variable fault behavior [e.g., Schwartz, 1989; Scholz, 1989] also imply the nonrandom occurrence of large earthquakes.

There is considerable debate as to how widely and over what imescale the "characteristic earthquake" and other models of periodic fault behavior may apply [cf. Nishenko, 1991; Nishenko and Sykes, 1993; Kagan and Jackson, 1994, 1995; Roeloffs and Langbein, 1994]. While the behavior of some faults appears to be governed by characteristic earthquakes over several earthquake cycles [e.g., Schwartz and Coppersmith, 1984] and others by temporal clusters of earthquakes [e.g., Wallace, 1987; Coppersmith, 1988; Sieh et al., 1989], comparisons of seismicity at the scale of plate boundary segments have indicated nonperiodic fault behavior [Kagan and Jackson, 1995].

Recent analysis of historic seismicity and geological fault-slip data from southern Califormia [Wesnousky, 1994] indicates that the structurally mature faults of the San Andreas fault zone do exhibit characteristic behavior, at least over the time periods $\left(10^{2}-10^{4}\right.$ years) considered. In North Canterbury, one historic surface rupture of the Hope River segment of the Hope fault (Figure la), together with paleoseismic data and spatial variations in late Quaternary slip rate from the same segment, are also consistent with the characteristic earthquake model [Cowan, 1990, 1991; Cowan and McGlone, 1991]. Elsewhere in New Zealand, significant variations in fault behavior have been documented [Berryman and Beanland. 1991], and the problem there, as in most parts of the world, is one of reconciling geological and seismological data spanning different time periods. The seismicity catalogue for New Zealand spans only the last 150 years for large earthquakes, and the instrumental catalogue spans a much shorter period. This problem is intractable and acknowledged in seismicity rate analysis and hazard estimation. However, the historic catalogue for North Canterbury is sufficiently long to illustrate significant discrepancies between recurrence rates for large earthquakes extrapolated from the historic catalogue versus recurrence rates implied by geological data.

\section{Frequency-Magnitude Relations for North Canterbury Seismicity}

\section{Seismicity Zones}

For the purpose of comparing historic seismicity and paleoseismic data , two $100 \times 50 \mathrm{~km}$ zones (Figures $1 \mathrm{a}$ and $1 \mathrm{~b}$ ) were selected, based on the contrasting structural maturity and geological slip rates of the known faults. Zone 1 encompasses an -35 - km-long releasing bend in the Hope fault zone across which about half $(\sim 10-$ $14 \mathrm{~mm} / \mathrm{yr}$ ) of the total Hope fault slip rate is localized on the Hope River segment, with the remainder distributed across adjacent plays, notably the Kakapo fault [Cowan, 1990: Van Dissen and Yeats, 1991; Yang, 1991] (Figure 1a). The Hope fault has a cumulative offset of $\sim 20 \mathrm{~km}$ [Freund, 1971], and its total slip rate $(\sim 25 \mathrm{~mm} / \mathrm{yr})$ is equivalent to more than $60 \%$ of the total rate of relative plate motion [DeMets et al., 1990], which represents the highest rate of slip in the Marlborough Fault System [Van Dissen and Yeats, 1991]. The last surface rupture in zone 1 occurred on the Hope River segment during an $M \sim 7.3$ earthquake in 1888 (Figure 1a) [McKay, 1890; Cowan, 1991]. The Hope River segment has ruptured repeatedly at intervals of $80-200$ years during the last millenium. or approximately every 140 years during the last 3500 years, if the slip rate and local offset in the 1888 event are included [Cowan and McGlone, 1991] (Table 3).

Zone 2 is centered on the PPAFZ whose cumulative offset and slip rate is approximately one order of magnitude smaller than the Hope fault. Both zone 1 and zone 2 contain additional faults associated with Holocene surface traces, for which little or no paleoseismic data are available [Wood et al., 1994; this study]. Uncertainties in the location of historic earthquakes smaller than magnitude M 4.0, preclude the selection of smaller zones adjacent to the major faults [cf. Wesnousky. 1994]. However, the depth distribution of seismicity recorded during microearthquake surveys in zone 1 [Arabasz and Robinson, 1976; Kieckhefer, 1977] and zone 2 [Reyners and Cowan. 1993] indicates that most seismicity is restricted to the upper 10-15 $\mathrm{km}$ of the crust. By conservatively choosing $50 \mathrm{~km}$ wide zones for seismicity rate analysis in this study, we are therefore confident that all seismicity associated with the major seismogenic faults has been sampled.

\section{Seismicity Distribution and Recurrence Parameters}

Three time periods were selected based on the relative completeness of the seismicity catalogue: for events $M>5$ since $1942 ; M>4$ since 1964 and $M>3$ since 1988. Only those events with crustal depths (i.e., restricted and free depths shallower than $4 \mathrm{~km}$ ) were sampled, so as to exclude events located in the subducted Pacific plate $100 \mathrm{~km}$ beneath the Hope fault region [Robinson, 1991]. The catalogue was also truncated at May 30, 1994, to avoid sampling those aftershocks of the June 1994 Arthur's Pass earthquake that fall within the northwestern comer of zone 2 (Figure lb).

The instrumental seismicity catalogue for zone 1 contains a number of events of magnitude $M$ 4.0-6.4. mainly in the east. Several of these events are associated with two swarms, the first of which occurred south of the Hope fault on May 22. 1948, and comprised six events $\left(M_{L}=5.9,6.4,6.2,5.7,5.7\right.$, and 5.8) within the space of 2 hours and 24 min [Eiby, 1982]. The second swarm (April $22-28,1973)$ consisted of four events $\left(M_{L}=5.2,4.5,4.4\right.$, and 5.0) in an area northeast of the Hope fault [Reyners, 1989]. Only the largest event of that swarm lies within the northeastern comer of zone 1. Neither of the two swarms can be attributed to movement on known faults, but the Seismological Observatory File locations suggest that they are probably unrelated to the Hope fault.

One interesting feature of the catalogue for zone 1 is the absence of events of any magnitude in the western part of the region and farther west, where the 1888 and 1929 ruptures occurred (Figure lb). This quiescence was also apparent during an earlier study of microseismicity [Arabasz and Robinson, 1976] and may reflect a significant reduction of stress in that region following the large historic earthquakes.

The seismicity catalogue for zone 2 (Figure 1b) clearly shows diminishing activity south of the PPAFZ, but the strike of that zone is remarkably well-defined as noted by Reyners [1989], despite all but one event $(M-6.2)$ [Eiby, 1990], being smaller than $M$ 5.5. A recent study of microseismicity in North Canterbury [Cowan, 1992; Reyners and Cowan, 1993; H.A. Cowan et al., manuscript in preparation, 1995] has also shown seismicity clustered along the 
Table 3. Magnitude-Frequency Relations Within the Hope Fault Region (Zone 1) and Porter's Pass-to-Amberley Fault Zone (Zone 2)

\begin{tabular}{|c|c|c|c|c|c|c|c|c|c|}
\hline \multirow{2}{*}{$\begin{array}{c}\text { Period } \\
\text { (Number of } \\
\text { Years) }\end{array}$} & \multirow{2}{*}{$\begin{array}{l}\text { Threshold } \\
\text { Magnitude }\end{array}$} & \multirow{2}{*}{$\begin{array}{l}\text { Number of } \\
\text { Events } \\
\text { Regressed }\end{array}$} & \multicolumn{4}{|c|}{ Recurrence Parameters } & \multicolumn{3}{|c|}{ Return Periods (years) } \\
\hline & & & $a$ & SE & $b$ & SE & $M 6^{\mathrm{S}}$ & $M 7^{\mathrm{s}}$ & $M>7^{\mathrm{P}}$ \\
\hline \multicolumn{10}{|c|}{ Hope Fault Region (Zone 1) } \\
\hline $1942-1994$ & M 5 & 10 & 3.76 & 0.47 & $0.87^{\mathrm{a}}$ & 0.08 & 29 & 214 & \multirow[b]{2}{*}{$80-200^{b}$} \\
\hline$(52.5)$ & & & 3.64 & .0 .47 & 0.85 & 0.08 & 29 & 204 & \\
\hline $1964-1994$ & M 4 & 4 & 3.31 & 0.22 & $0.87^{\mathrm{a}}$ & 0.05 & 81 & 602 & \multirow[b]{2}{*}{$60-300^{c}$} \\
\hline (30.5) & & & 3.22 & 0.22 & 0.85 & 0.05 & 76 & 537 & \\
\hline $1988-1994$ & M 3 & 32 & 4.33 & 0.23 & $1.20^{\mathrm{g}}$ & 0.06 & - & - & \\
\hline (6.5) & & & 3.14 & 0.43 & 0.87 & 0.12 & 120 & 891 & \\
\hline \multicolumn{10}{|c|}{ PPAFZ Region (Zone 2) } \\
\hline $1942-1994$ & M5 & 6 & 1.83 & 0.75 & 0.60 & 0.13 & 59 & 234 & 1300 \\
\hline$(52.5)$ & & & 3.33 & 0.88 & 0.87 & 0.16 & 78 & 575 & $2000^{d}$ \\
\hline 1964-1994 & M 4 & 20 & 3.01 & 0.35 & 0.81 & 0.07 & 71 & 457 & \multirow[b]{2}{*}{$750-1000^{\circ}$} \\
\hline$(30.5)$ & & & 3.29 & 0.36 & 0.87 & 0.08 & 85 & 631 & \\
\hline $1988-1994$ & M3 & 48 & 3.81 & 0.13 & $0.97^{\mathrm{a}}$ & 0.04 & 102 & 955 & \multirow{2}{*}{$1500-2000^{f}$} \\
\hline (6.5) & & & 3.43 & 0.17 & 0.87 & 0.05 & 62 & 457 & \\
\hline
\end{tabular}

Except as otherwise noted, $b$ was determined through an iterative procedure in which only $a$ was allowed to vary. Two sets of recurrence parameters are given for each of the three time periods in order to evaluate the sensitivity of $a$ and $b$ values. The standard errors (SE) indicate no significant differences in $a$ for different values of $b$. The superscript $S$ and $\mathbf{P}$ denote historical return periods implied by seismicity and paleoseismic data, respectively.

The $a$ and $b$ cases were determined simultaneously by a linear least squares fit.

bowan and McGlone [1991].

c Calculated using slip rate of 10-25 m/kyr and slip per event of 1.5-3.0 m. Data are from Cowan and McGlone [1991] and Van Dissen and Yeats [1991].

${ }^{\mathrm{d}}$ From landslide and fault rupture data (this study).

- Calculated using a slip rate of 3-4 m/kyr and slip per event of $3 \mathrm{~m}$. Slip rates from Berryman [1979] and Knuepfer [1992].

f Calculated using a slip rate of 3-4 m/kyr and slip per event of $6 \mathrm{~m}$. Slip rates from Berryman [1979] and Knuepfer [1992].

PPAFZ, with most events confined to the upper $8-15 \mathrm{~km}$ of the crust.

The recurrence parameters $a$ and $b$ of the Gutenberg-Richter relation were computed for the PPAFZ and Hope fault regions using ordinary least squares regression and an iterative approach to the selection of $b$ values (Table 3 ). The recurrence parameters listed in Table 3, and illustrated for the period 1964-1994 in Figure 7, indicate negligible differences in activity rates between the selected regions, despite an order of magnitude difference in slip rate and cumulative offset. By contrast, the paleoseismic data from each region imply significant differences in recurrence intervals for large earthquakes (Table 3), yet neither could be reliably predicted from the historic seismicity catalogue.

In zone 1 the presence of many additional faults with potential to generate large earthquakes in the Hope fault region emphasizes the deceptiveness of contemporary seismicity. Moreover, the discrepency between recurrence rates for large earthquakes inferred from historical and geological data would be accentuated if the swarm earthquakes mentioned above were to be excluded from the analysis; i.e., the seismicity rate above magnitude 5 would be even lower in zone 1 during the historical period. The situation is different in zone 2 , where the discrepency between historic and paleoseismic data is in the opposite sense (Table 3 ). There, the recurrence rate for large earthquakes is approximated by the
Gutenberg-Richter model (Figure 7), but the closest match between the historical and geological data and the smallest errors for the historical recurrence parameters are obtained from the magnitude frequency distribution of $M>3$ earthquakes since 1988 (Table 3). The recurrence estimates for large earthquakes derived from longer periods of historical seismicity in zone 2 are higher than those implied by the paleoseismic data (Table 3 ).

\section{Discussion}

Further interpretation of the historical seismicity data may be unwarranted given that the seismicity catalogue is possibly too short to sustain a robust "productivity" analysis at magnitudes less than $M 4$. The historical data in the magnitude range $M<6.0$ straddle a period of seismic quiescence in the Hope fault region, which mry not be representative of the longer-term seismicity rate. Similarly, the relatively high rate of seismicity in the PPAFZ during the last 30 years may reflect long-term temporal variations in deformation and clustering of earthquake occurrence, as for example, inferred from comparisons of low geological slip rate but higher geodetic strian and seismicity rates, in the reverse fault province of northwesterl South Island [H. Anderson et al., 1993; Beavan et al., 1994]. 

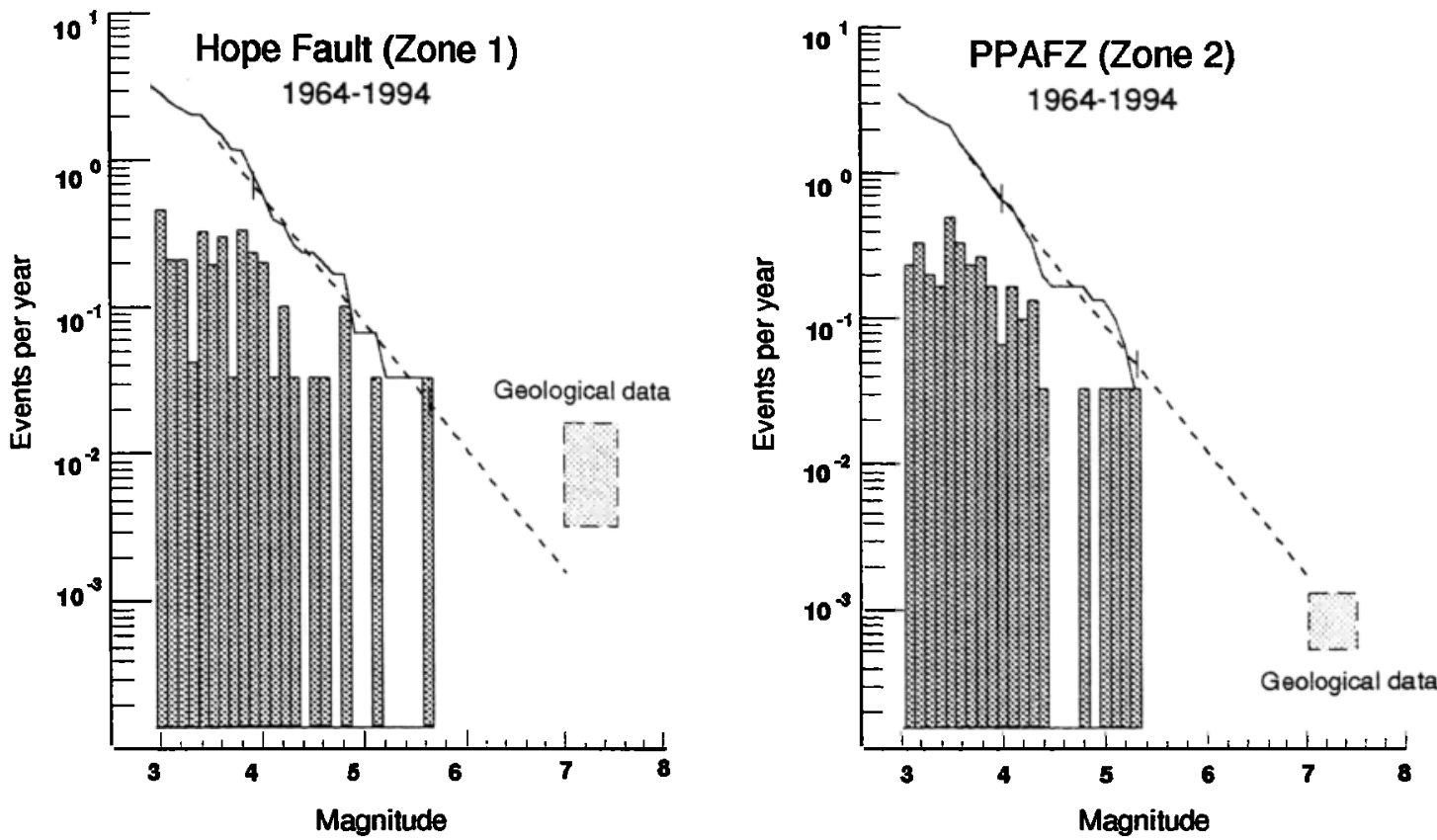

Figure 7. Comparison of frequency-magnitude relations for the Hope fault (Zone 1) and PPAFZ (Zone 2) (Figure 1b) for the period 1964-1994. The frequency histograms were compiled at class intervals of M 0.1. The solid line represents the cumulative frequency, whereas the dashed straight line denotes the best fit ( $b$ value 0.87 ) for the magnitude range defined by vertical ticks. The shaded boxes indicate the recurrence rate and possible magnitude for large earthquakes inferred from geological data. The magnitude-frequency distribution for the Hope fault is in accord with the characteristic earthquake model, whereas that of the PPAFZ is approximated by the Gutenberg-Richter model. Note in Table 3, however, that the Gutenberg-Richter relationship overpredicts the recurrence rate of $M$ $>7$ earthquakes in the PPAFZ.

Temporal variations in seismicity rate may profoundly affect the frequency-magnitude distribution and apparent relationships between seismic productivity and fault slip rate, structural complexity, or maturity. For example, had it been possible to sample seismicity in the Hope fault region for the 50 years straddling the 1888 earthquake, the productivity could have been higher and the frequency-magnitude relationships implied by such data might not have underpredicted the recurrence rate for the largest events on the Hope fault to the same degree as the current data set (Table 3). Conversely, low seismicity rates may typify the behavior of the Hope fault, since it is clear that the $M \sim 7.3$ event of one century ago has not been followed by ongoing high rates of activity.

Return periods for large rare events are clearly sensitive to slight changes in recurrence parameters when regressions are performed on data dominated by smaller events, or when the catalogue is heterogeneous with respect to magnitude [e.g., Okal and Romanowicz, 1994; Kagan and Jackson, 1995]. It is perhaps ironic therefore that the closest match between the historical and geological data from the PPAFZ should be obtained from only 6.5 years (1988-1994) of seismicity data (Table 3), given that recurrence estimates based on such a short time period would be assigned a low weighting in any seismic hazard assessment of that region.

The available paleoseismic data show that even at this early stage of development, elements of the PPAFZ are amenable to paleoseismic investigation. The apparent absence of large landslides or surface ruptures with ages between or younger than 500-700 and 2000-2500 years B.P. indicates that the data for the late Holocene may be complete. However, it is clear from the distribution of landslide ages that evidence for events older than $\sim 2500$ years is only sparsely preserved. Moreover, while the combined evidence of faulting and landslides between 2000 and 2500 years B.P. is quite compelling, this cannot be said of the 500 700 year B.P. event, for which our interpretation rests largely on the landslide data alone.

If our record of late Holocene rupture of the PPAFZ is complete, the implied interval of 1300-2000 years between the last two events would require $4.8 \mathrm{~m}$ displacement per event to be consistent with the inferred slip rate of $3-4 \mathrm{~mm} / \mathrm{yr}$ on the Porter's Pass fault. Displacements per event of this order have been documented for numerous Holocene faults throughout New Zealand [Berryman and Beanland, 1991] and Árnudóttir et al. [1995] have modeled up to 5 m of displacement for the 1994 Arthur's Pass earthquake (Figure 1a). Thus the inferred retum period, displacement per event, and slip rate need not be inconsistent. Moreover, it seems reasonable to conjecture that larger displacements per event could be expected within a newly formed fault zone composed of numerous short $(<10$ km) segments that might accommodate more elastic strain than a mature fault which has undergone strain softening. The behavior of the PPAFZ at its present stage of development could therefore be more consistent with that of intra-plate fault zones, i.e., characterized by low slip rate, more interseismic fault healing processes, and larger slip or stress drop per event [Kanamori and Allen, 1986].

Although the available recurrence and displacement estimates for large earthquakes in the PPAFZ are consistent with the inferred geological slip rate of the Porter's Pass fault, we cannot discount the possibility that the slip per event is less than that required to account for the total strain, which recent studies have shown to be geodetically measurable at well over the $95 \%$ confidence level 
(Pearson et al., submitted manuscript, 1995). At present, slip rates for faults in the central and eastern parts of the PPAFZ are too poorly defined to permit moment rate summation for direct comparison with rates of geodetic strain, but it is possible that some fraction of the slip across the PPAFZ is distributed among secondary structures, or accommodated by smaller earthquakes than we presently recognize in the geological record. One of several explanations advanced to explain a historic deficit of moment release in California [e.g., Dolan et al., 1995] is that a larger fraction of the total slip rate across that region is released by more frequent moderate (M 6-6.5) earthquakes for which there is less geological evidence [Ward, 1994; Wesnousky, 1994]. Alternatively, a proportion of the strain may be accommodated by relatively aseismic slip in numerous small earthquakes [e.g., Lin and Stein, 1989; Hill et al., 1990]. In the PPAFZ, the historical seismicity rates may be "randomly" high for the sampled time periods and magnitude range considered, but it is also plausible that the frequency of large earthquakes may be quasi-periodic and governed by factors unique to a fault zone in the early stages of development.

\section{Conclusions}

Dated surface ruptures and landslides corroborate an inference of two large $(M>7.0)$ earthquakes within the PPAFZ during the last -2500 years. Two earlier events during the Holocene are also recognized, but the data prior to 2500 years are presumed to be incomplete. A return period of 1300-2000 years for rupture of the PPAFZ would be consistent with the inferred slip rate $(3-4 \mathrm{~mm} / \mathrm{yr})$ of its principal element, the Porter's Pass fault, provided that the slip per event is in the range $4-8 \mathrm{~m}$.

Paleoseismic data from the adjacent structurally mature Hope fault zone farther north indicate significant differences in fault behavior with respect to the PPAFZ, with recurrence intervals for large earthquakes apparently differing by a factor of 5 or more. Paradoxically, the differences in historical seismicity rates for the Hope fault and PPAFZ ( zones 1 and 2, respectively. Figure 1b) are negligible despite an order of magnitude difference in slip rate and cumulative offset associated with the major faults. The magnitudefrequency distribution for the Hope fault region is in accord with the characteristic earthquake model, whereas the magnitude-frequency distribution in the PPAFZ is approximated, but slightly overpredicted, by the Gutenberg-Richter relationship (Table 3 and Figure 7). The comparison of these two fault zones demonstrates the importance of the structural maturity of the fault zone in relation to seismicity rates inferred from recent, historical, and paleoseismic data.

Acknowledgments. This study was funded by the New Zealand University Grants Committee and New Zealand Earthquake Commission, and formed part of a Ph.D. programme within the Active Tectonics Research Group at the University of Canterbury. Brian Molloy and Neville Moar provided radiocarbon ages and pollen data from sites at Porter's Pass. We thank Warwick Smith and the New Zealand Seismological Observatory for seismicity data and Conrad Lindholm for help with data reprocessing at NORSAR. Reviews by John Adarns, Kelvin Berryman, Bill Bull, Hilmar Bungum, Jarg Pettinga, Mauri McSaveney, Mark Stirling, and Bob Yeats improved the paper and provided impetus to extend some aspects of the work, which was completed while the first author worked at the Norwegian Geotechnical Institute and Norwegian Seismic Array (NORSAR), supported by a fellowship from the Research Council of Norway.

\section{References}

Adams, J., Earthquake-dammed lakes in New Zealand, Geology, 9, 215219, 1981.

Adams, R.D., G.A. Eiby, M.A. Lowry, G.J. Lensen, R.P. Suggate,and W.P.
Stephenson, Preliminary reports on the Inangahua earthquake, New Zealand, May 1968, DSIR Bull. 193, 1968.

Amaike, F., Seismic explorations of the buried fault associated with the 1948 Fukui earthquake, J. Phys. Earth, 35, 285-308, 1987.

Anderson, H., T. Webb, and J. Jackson, Focal mechanisms of large earth. quakes in the South Island of New Zealand: Implications for the accommodation of Pacific-Australia plate motion, Geophys. J. Int., 115, 1032. $1054,1993$.

Anderson, H., S. Beanland, G. Blick, D. Darby, G. Downes, J. Haines, J. Jackson, R. Robinson, and T. Webb, The 1968 May 23 Inangahua, New Zealand, earthquake: An integrated geological, geodetic, and seismological source model, N.Z. J. Geol. Geophys., 37, 59-86, 1994.

Anderson, J.G., M. Ellis, and C. DePolo, Earthquake rate analysis, Tectonophysics, 218, 1-21, 1993.

Arabasz, W.J., and R. Robinson, Microseismicity and geological structure in the northem South Island, New Zealand, N. Z. J. Geol. Geophys., IS, 569-601, 1976.

Árnadóttir, T., J. Beavan, and C. Pearson, Deformation associated with the 18 June, 1994, Arthur's Pass earthquake, New Zealand, NZ. J. Geol. Geopltys., in press, 1995.

Barnes, P.M., Structural styles and sedimentation at the southem termint. tion of the Hikurangi subduction zone, offshore North Canterbury, New Zealand, Ph.D. thesis, Univ. of Canterbury, Christchurch, New Zealand, 1994.

Beavan, J., D. Darby, G. Blick, C. Pearson, T. Ámadóttir, R.I. Walcott, B. Parsons, and P. England, GPS measurements at the transition between continental collision and subduction on the Pacific-Australian piate boundary in New Zealand, Eos Trans. AGU, 75(44), Fall Meet. Suppl, $669,1994$.

Berryman, K., Active faulting and derived PHS directions in the South Island, New Zealand, in The Origin of the Southern Alps edited by R. Walcott and M.M. Cresswell, Bull. R. Soc. N.Z., 18, 29-34, 1979.

Berryman, K.R., and S. Beanland, Variation in fault behavior in differen tectonic provinces of New Zealand, J. Struct. Geol., 13, 177-189, 1991.

Brown, L.J., Geological map of New Zealand, sheet S76 "Kaiapoi", 1st ed scale 1:63,360, Dep. of Sci. Ind. Res., Wellington, New Zealand, 1973.

Bull, W.B., J. King, F. Kong, T. Moutoux, and W.M. Phillips, Lichen dating of coseismic landslide hazards in alpine mountains, Geomorphology, 10, 253-264, 1994.

Burrows, C.J., A 500-year old landslide in the Acheron River valley, Carterbury, N.Z. J. Geol. Geophys., 18, 357-360, 1975.

Carter, R.M., and L. Carter, The Motunau Fault and other structures at the southern edge of the Australian-Pacific plate boundary, offshore Marborough, New Zealand, Tectonophysics, 88, 133-159, 1982.

Chinn, T.J.H., Use of rock weathering-rind thickness for Holocene absolute age-dating in New Zealand, Arct. Alp. Res., 13, 33-45, 1981.

Coppersmith, K.J., Temporal and spatial clustering of earthquake activity it the central and eastem United States, Seismol. Res. Lett., 59, 299-304, 1988.

Cornell, C.A., Engineering seismic risk analysis, Bull. Seismol. Soc. Am, 58, 1583-1606, 1968.

Cowan, H.A., Late Quaternary displacements on the Hope fault at Glyan Wye, North Canterbury, N.Z.J. Geol. Geophys., 33, 285-293, 1990.

Cowan, H.A., The North Canterbury earthquake of September 1, 1888, d. R. Soc. N.Z., 21, 1-12, 1991.

Cowan, H.A., Structure, seismicity and tectonics of the Porter's Pas Amberley Fault Zone, North Canterbury, New Zealand. Ph.D. thesis Univ. of Canterbury, Christchurch, New Zealand, 1992.

Cowan, H.A., (Compilor), Field guide to New Zealand active tectonict IASPEI 94, 27th General Assembly of IASPEI, January 1994, Welling ton, R. Soc. N.Z. Misc. Ser., 27, 1994.

Cowan, H.A., and M.S. McGlone, Late Holocene displacements and chr acteristic earthquakes on the Hope River segment of the Hope fall New Zealand, J.R. Soc. N.Z., 21, 373-384, 1991.

Coyle, S., The Porter's Pass Fault, M.Sc. thesis, Univ. of Canterbuy. Christchurch, New Zealand, 1988.

Davis, T.L., and J.S. Namson, A balanced cross-section of the 194 Northridge earthquake, southern California, Nature, 372, 167-169, 1994.

Davison, F.C., and C.H. Scholz, Frequency-moment distribution of eart quakes in the Aleutian Arc: A test of the characteristic earthquate model, Bull. Seismol. Soc. Am., 75, 1349-1361, 1985.

DeMets, C., R.G. Gordon, D.F. Argus, and S. Stein, Current plate motion Geophys. J. Int., 101, 425-478, 1990.

Doig, R., $2300 \mathrm{yr}$ history of seismicity from silting events in Lake Tadow sac, Charlevoix, Quebec, Geology, 18, 820-823, 1990. 
Dolan, J.F, K. Sieh, T.K. Rockwell, R.S. Yeats, J. Shaw, J. Suppe, G.H Huftile, and E.M. Gath, Prospects for larger or more frequent earthquakes in the Los Angeles metropolitan region, Science, 267, 199-205, 1995.

Dowrick, DJ., and E.G.C. Smith, Surface wave magnitudes of some New Zealand earthquakes 1901-1988, Bull. N. Z. Nat. Soc. Earthquake Eng. $23,198-219,1990$.

Eiby, G.A., An annotated list of New Zealand earthquakes, 1460-1965, NZ.J. Geol. Geophys., II, 630-647, 1968.

Eiby, G.A., New Zealand seismological report 1948-49-50, Bull. E-164, Seismol. Obs., Wellington, New Zealand, 1982.

Eiby, G.A., The Lake Coleridge earthquakes of 1946, Bull. N.Z. Nat. Soc. Earthquake Eng., 23, 150-158, 1990.

Freund, R., The Hope Fault: A strike-slip fault in New Zealand, N.Z. Geol. Surv. Bull., 86, 1971.

Garlick, R., Lees Valley Fault. B.Sc.(Hons) dissertation, Univ. of Canterbury, Christchurch, New Zealand, 1992.

Gegg, D.R., Geological map of New Zealand sheet i8, "Hurunui" scale 1:250,000, NZ. Dep. of Sci. Ind. Res., Wellington, New Zealand, 1964.

Henderson, J., West Nelson earthquake of 1929, NZ. J. Sci. Technol., 19, 66-144, 1937.

Herzer, R.H., and J.D. Bradshaw, The Motunau Fault and other structures at the southern edge of the Australian-Pacific plate boundary, offshore Marlborough, New Zealand, Tectonophysics, 115, 161-166, 1985.

Hill, D.P., J.P. Eaton, and L.M. Jones, Seismicity 1980-86, in The San Andreas Fault System, California, US. Geol. Surv. Prof. Pap. 1515, 115-151, 1990.

Hull, A.G., Tectonics of the 1931 Hawke's Bay earthquake, NZ. J. Geol. Geophys., 33, 309-320, 1990.

Jibson, R.W., C.S. Prentice, B.A. Borisoff, E.A. Rogozhin, and CJ. Langer, Some observations of landslides triggered by the 29 April, 1991, Racha earthquake, Republic of Georgia, Bull. Seismol. Soc. Am., 84, 963-973, 1994.

Kagan, Y.Y., and D.D. Jackson, Long-term probabilistic forecasting of earthquakes, J. Geophys. Res., 99, 13,685-13,700, 1994.

Kagan, Y.Y., and D.D. Jackson, New seismic gap hypothesis: Five years after, J. Geophys. Res., 100, 3943-3959, 1995.

Kanamori, H., and C.R. Allen, Earthquake repeat time and average stress drop, in Earthquake Source Mechanics, Geophys. Monogr. Ser., vol. 37, edited by S. Das, J. Boatwright, and C.H. Scholz, pp. 157-167, AGU, Washington, D.C., 1986.

Keefer, D.K., Landslides caused by earthquakes, Geol. Soc. Am. Bull., 95 , 406-421, 1984.

Bieckhefer, R.M., Microseismicity in the vicinity of the Clarence fault, New Zealand, NZ. J. Geol. Geophys., 20, 165-177, 1977.

King, G.C.P., The accommodation of large strains in the upper lithosphere of the earth and other solids by self-similar fault systems: The geometrical origin of b-value, $P$ ure Appl. Geophys., $121,762-815,1983$.

King, G.C.P., and J. Nabelek, The role of bends in faults in the initiation and termination of earthquake rupture, Science 228, 984-987, 1985.

Kirkaldy, P.H.S., and E.G. Thomas, Final report on a seismic survey in the Canterbury Plains area of New Zealand, BP Shell and Todd Petroleum Development Ltd, $N Z$ Z. Geol. Surv. Open File Pet. Rep., 328, 1963.

Knyepfer, P.L.K., Temporal variations in latest Quaternary slip across the Australian-Pacific plate boundary, northeastern South Island, New Zealand, Tectonics, $11,449-464,1992$.

Lin, J., and R.S. Stein, Coseismic folding, earthquake recurrence and the 1987 source mechanism at Whittier Narrows, Los Angeles Basin, California, J. Geophys. Res., 94, 9614-9632, 1989.

McKay, A., On the earthquakes of September 1888, in the Amuri and Marlborough districts of the South Island, N.Z. Geol. Surv. Rep. Geol. Explor., 20, 1-16, 1890.

McKay, A., Report on the recent seismic disturbances within Cheviot County in northem Canterbury and the Amuri District of Nelson, New Zealand, Govt. Print., Wellington, New Zealand, 1902.

McSaveney, M.J., Sherman Glacier rock avalanche, Alaska, U.S.A., in Rockslides and Avalanches 1, edited by B.Voight, pp. 197-258, Elsevier Sci., New York, 1978.

McSaveney, MJ., A manual of weathering-rind dating for sandstone of the Torlesse Supergroup, Tech. Rep. 92/4, N.Z. Inst. of Geol. and Nucl. Sci. Wellington, New Zealand, 1992.

McSaveney, MJ., Rock avalanches of 2 May and 16 September 1992, Mount Fletcher, New Zealand, Landslide News, 7, 2-4, 1993.

MeSaveney, MJ., T.J. Chinn, and G.T. Hancox, Mount Cook rock avalanche of 14 December 1991. New Zealand, Landslide News, 6, 32-34 1992.
New Zealand Seismological Observatory, New Zealand earthquakes: 18501994. Observatory Master File, Inst. of Geol. and Nucl. Sci., Wellington, New Zealand, 1994.

Nicol, A., B.V. Alloway, and PJ. Tonkin, Rates of deformation, uplift and landscape development associated with active folding in the Waipara area of North Canterbury, New Zealand, Tectonics, 13, 1327-1344, 1994.

Nishenko, S.P., Circum-Pacific seismic potential: 1989-1999, Pure Appl. Geophys., 135, 169-259, 1991.

Nishenko, S.P., and L.R. Sykes, Comment on "Seismic gap hypothesis: Ten years after" by Y.Y. Kagan and D.D. Jackson, J. Geophys. Res., 98 , 9909-9916, 1993.

Okal, E.A., and B.A. Romanowicz, On the variation of b-values with earthquake size, Phys. Earth Planet. Inter., 87, 55-76, 1994.

Pearson, G.W., and M. Stuiver, High-precision calibration of the radiocarbon time scale, 500-2500 BC, Radiocarbon, 28, 839-862, 1986.

Peek, R., J.B. Berrill, and R.O. Davis, A seismicity model for New Zealand, Bull. NZ. Nat. Soc. Earthquake Eng., 13, 355-364, 1980.

Plafker, G., and G.E. Ericksen, Nevados Huascaran avalanches, Peru, in Rockslides and Avalanches 1, edited by B. Voight, pp. 277-314, Elsevier Sci., New York, 1978.

Reyners, M.E., New Zealand seismicity 1964-87: An interpretation, NZ.J. Geol. Geophys., 32, 307-315, 1989.

Reyners, M.E. and H.A. Cowan, The transition from subduction to continental collision: crustal structure in the North Canterbury region, New Zealand, Geophys. J. Int., 115, 1124-1136, 1993.

Robinson, R. Extent and geometry of subduction in the northern South Island and Wellington regions, New Zealand, Geol. Soc. NZ. Misc. Publ., 56, 44-46, 1991.

Roeloffs, E., and J. Langbein, The earthquake prediction experiment at Parkfield, Califomia, Rev. Geophys., 32, 315-336, 1994.

Rynn, J.M.W, and C.H. Scholz, Seismotectonics of the Arthur's Pass region, south Island, New Zealand, Geol. Soc. Am. Bull., 89, 1373-1388, 1978.

Scholz, C.H., Comments on models of earthquake recurrence, in , Proceedings of Conference XLV - Fault Segmentation and Controls of Rupture Initiation and Termination, edited by D.P. Schwartz and R.H. Sibson, US. Geol. Surv. Open File Rep., 89-315, 350-360, 1989.

Schwartz, DP., Paleoseismicity, persistence of segments, and temporal clustering of large earthquakes-Examples from the San Andreas, Wasatch, and Lost River fault zones, in, Proceedings of Conference XLV - Fault Segmentation and Controls of Rupture Initiation and Termination, edited by D.P. Schwartz and R.H. Sibson, US. Geol. Surv. Open File Rep., 89-315, 361-375, 1989.

Schwartz, D.P., and KJ. Coppersmith, Fault behavior and characteristic earthquakes: Examples from Wasatch and San Andreas Faulis, J. Geophys. Res., 89,5681-5698, 1984.

Shaw, J., and J. Suppe, Active faulting and growth folding in the eastern Santa Barbara Channel, Califomia, Geol. Soc. Am. Bull., 106, 607-626, 1994.

Sibson, R.H., Stopping of earthquake ruptures at dilational fault jogs, Nature, 316, 248-251, 1985.

Sibson, R.H., Earthquake faulting as a structural process, J. Struct. Geol., $11,1-14,1989$.

Sieh, K., M. Stuiver, and D. Brillinger, A more precise chronology of earthquakes produced by the San Andreas fault in southern California, $J$. Geophys. Res., 94, 603-623, 1989.

Skey, H.F., Report on the North Canterbury earthquake of 25th December, 1922, in Record Survey N.Z., Dept. of Lands and Surv., Wellington, New Zealand, 1925.

Smalley, R., J. Pujol, M. Regnier, J.M. Chiu, J.L. Chatelain, B.L. Isacks, M Araujo, and N. Puebla, Basement seismicity beneath the Andean Precordilleran thin-skinned thrust belt and implications for crustal and lithospheric bebavior, Tectonics, 12, 63-76, 1993.

Smith, W.D., and K.R. Berryman, Earthquake hazard in New Zealand: Inferences from seismology and geology, Bull. Roy. Soc. N.Z., 24, 223242, 1986.

Speight, R., The Arthur's Pass earthquake of 9th March, 1929, NZ. J. Sci. Technol., 15, 173-182, 1933.

Speight, R., Recent faulting in the Southern Alps, N.Z. J. Sci. Technol., 19, $701-708,1938$

Stein, R.S., and G. Ekstrem, Seismicity and geometry of a $110 \mathrm{~km}-\mathrm{long}$ blind thrust fault, 2, Synthesis of the 1982-1985 California earthquake sequence, J. Geophys. Res., 97, 4865-4883, 1992.

Stein, R.S., and R.S. Yeats, Hidden earthquakes, Sci. Am., 260 (6), 30-39, 1989. 
Stuiver, M., and G.W. Pearson, High-precision calibration of the radiocarbon time scale AD 1950-500 BC, Radiocarbon, 28, 805-838, 1986.

Stuiver, M., and P.J. Reimer, A computer program for radiocarbon age calibration, Radiocarbon, 28, 1022-1030, 1986

Tonkin, P.J., and L.R. Basher, Soil-stratigraphic techniques in the study of soil and landform evolution across the Southern Alps, New Zealand, Geomorphology, 3, 547-575, 1990.

Trangmar, B.B., Overview of Canterbury loess deposits: Tour guide for Int. Symp. on Loess: February 14-21, presented at Third Meeting of Westen Pacific, INQUA Loess Comm., Christchurch, New Zealand, 1987.

Van Dissen, R., and R.S. Yeats, Hope Fault, Jordan thrust, and uplift of the Seaward Kaikoura Range, New Zealand, Geology, 19, 393-396, 1991.

Wallace, RE., Grouping and migration of surface faulting and variations in slip rates on faults in the Great Basin province, Bull. Seismol. Soc. Am., $77,868-876,1987$.

Ward, S.N., A multidisciplinary approach to seismic hazard in southern California, Bull. Seismol. Soc. Am., 84, 1293-1309, 1994.

Wellman, H.W., Data for the study of Recent and late Pleistocene faulting in the south Island of New Zealand, NZ. J. Sci. Technol. B 34, 270-288, 1953.

Wells, D.L., and K.J. Coppersmith, New empirical relationships among magnitude, rupture length, rupture width, rupture area, and surface displacement, Bull. Seismol. Soc. Am., 84, 974-1002, 1994.

Wesnousky, S.G., Seismological and structural evolution of strike-slip faults, Nature, 335, 340-343, 1988.

Wesnousky, S.G., Seismicity as a function of cumulative geologic offset: some observations from southern California, Bull. Seismol. Soc. Am. 80, 1374-1381, 1990.

Wesnousky, S.G., The Gutenburg-Richter or characterisic earthquake distribution, which is it? Bull. Seismol. Soc. Am., 84, 1940-1959, 1994.

Wesnousky, S.G., C.H. Scholz, K. Shimazaki, and T. Matsuda, Earthquake frequency distribution and the mechanics of faulting, J. Geophys. Res., $88,9331-9340,1983$.

Whitehouse, I.E., and G.A. Griffiths, Frequency and hazard of large rock avalanches in the central Southern Alps, New Zealand, Geology, 11, $331-334,1983$.
Wilson, D.D., Geology of the Waipara subdivision, N.Z. Geol. Surv. Bull. 64, 122 pp., 1963.

Wood, R.A., J.R. Pettinga, S. Bannister, G. Lamarche, and T.J. McMoran, Structure of the Hanmer strike-slip basin, Hope fault, New Zealand, Geol. Soc. Am. Bull., 106, 1459-1473, 1994.

Working Group on California Earthquake Probabilities, Probabilities of large earthquakes in the San Fransisco Bay Region, California, US Geol. Surv. Circ., 1053, 51 pp., 1990.

Yang, J.S., The Kakapo Fault-A major active dextral fault in the centro North Canterbury-Buller regions of New Zealand, NZ. J. Geol. Geophys., 34, 137-143, 1991.

Yang, J.S., Landslide mapping and major earthquakes on the Kakapo fault, South Island, New Zealand, J. R.. Soc. NZ., 22, 205-212, 1992

Yeats, R.S., and K.R. Berryman, South Island, New Zealand, and Trams verse Ranges, California: A seismotectonic comparison, Tectonics, 6 , 363-376, 1987.

Youngs, R.R., and K.J. Coppersmith, Implications of fault slip rates and earthquake recurrence models to probabilistic seismic hazard estimates Bull. Seismol. Soc. Am., 75, 939-964, 1985.

Yousif, H.S., The applications of remote sensing to geomorphological neo tectonic mapping in North Canterbury, New Zealand, Ph.D. thesis Univ. Canterbury, Christchurch, New Zealand, 1987.

H. Cowan, Norwegian Seismic Array, P.O. Box 51, Kjeller, N-2007 Norway. (e-mail: hugh@trane.norsar.no)

A. Nicol, Fault Analysis Group, Department of Earth Sciences, University of Liverpool, Liverpool L69 3BX, England.

P. Tonkin, Department of Soil Science, Lincoln University, P.O. Box 4 Lincoln, New Zealand.

(Received September 23, 1994; revised May 15, 1995; accepted May 23, 1995. ) 